\title{
Radiative heating rates profiles associated with a springtime case of Bodélé and Sudan dust transport over West Africa
}

\author{
C. Lemaître ${ }^{1}$, C. Flamant ${ }^{1}$, J. Cuesta ${ }^{2}$, J.-C. Raut ${ }^{1}$, P. Chazette ${ }^{3}$, P. Formenti ${ }^{4}$, and J. Pelon ${ }^{1}$ \\ ${ }^{1}$ Laboratoire Atmosphères, Milieux, Observation Spatiales, UMR 8190, CNRS and Université Pierre et Marie Curie and \\ UVSQ, Paris, France \\ ${ }^{2}$ Laboratoire de Météorologie Dynamique, CNRS, Ecole Polytechnique and ENS, Palaiseau, France \\ ${ }^{3}$ Laboratoire des Sciences du Climat et l'Environnement, CEA, CNRS and UVSQ, Saclay, France \\ ${ }^{4}$ Laboratoire Interuniversitaire des Systèmes Atmosphériques, CNRS and Université Paris Est Créteil Val de Marne/ \\ Université Denis Diderot, Créteil, France
}

Received: 31 January 2010 - Published in Atmos. Chem. Phys. Discuss.: 7 April 2010

Revised: 4 August 2010 - Accepted: 26 August 2010 - Published: 1 September 2010

\begin{abstract}
The radiative heating rate due to mineral dust over West Africa is investigated using the radiative code STREAMER, as well as remote sensing and in situ observations gathered during the African Monsoon Multidisciplinary Analysis Special Observing Period (AMMA SOP). We focus on two days (13 and 14 June 2006) of an intense and long lasting episode of dust being lifted in remote sources in Chad and Sudan and transported across West Africa in the African easterly jet region, during which airborne operations were conducted at the regional scale, from the southern fringes of the Sahara to the Gulf of Guinea. Profiles of heating rates are computed from airborne LEANDRE 2 (Lidar Embarqué pour l'étude de l'Atmosphère: Nuages Dynamique, Rayonnement et cycle de l'Eau) and spaceborne CALIOP (Cloud Aerosol Lidar and Infrared Pathfinder Satellite Observations) lidar observations using two mineral dust model constrained by airborne in situ data and groundbased sunphotometer obtained during the campaign. Complementary spaceborne observations (from the Moderateresolution Imaging Spectroradiometer-MODIS) and in-situ observations such as dropsondes are also used to take into account the infrared contribution of the water vapour. We investigate the variability of the heating rate on the vertical within a dust plume, as well as the contribution of both shortwave and longwave radiation to the heating rate and the radiative heating rate profiles of dust during daytime and nighttime. The sensitivity of the so-derived heating rate is also analyzed for some key variables for which the associated un-
\end{abstract}

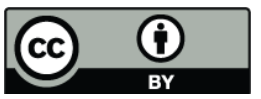

Correspondence to: C. Lemaître (cyndie.lemaitre@latmos.ipsl.fr) certainties may be large. During daytime, the warming associated with the presence of dust was found to be between $1.5 \mathrm{Kday}^{-1}$ and $4 \mathrm{Kday}^{-1}$, on average, depending on altitude and latitude. Strong warming (i.e. heating rates as high as $8 \mathrm{Kday}^{-1}$ ) was also observed locally in some limited part of the dust plumes. The uncertainty on the heating rate retrievals in the optically thickest part of the dust plume was estimated to be between 0.5 and $1.4 \mathrm{Kday}^{-1}$. During nighttime much smaller values of heating/cooling are retrieved (less than $\pm 1 \mathrm{Kday}^{-1}$ ). Furthermore, cooling is observed as the result of the longwave forcing in the dust layer, while warming is observed below the dust layer, in the monsoon layer.

\section{Introduction}

The impact of dust on the climate system and the large uncertainties associated with the role of dust in the Earth's radiation budget are now widely recognized (e.g., Intergovernmental Panel on Climate Change , 2007). North Africa is the world's largest source of mineral dust. Satellite sensors consistently indicate that dust aerosol plumes are the most widespread, persistent and dense particulate contribution found on Earth (e.g., Prospero et al., 2002).

In the framework of the Bodélé Experiment (BodEx; Washington et al., 2006; Tegen et al., 2006), the SAharan Mineral dUst ExperiMent (SAMUM; Heintzenberg, 2009 and SAMUM 2; Weinzierl et al., 2008), and the African Monsoon Multidisciplinary Analysis (AMMA; Redelsperger et al., 2006), the impact of dust aerosols on the WAM (West

Published by Copernicus Publications on behalf of the European Geosciences Union. 
African Monsoon) dynamics (most notably via the aerosol semi-direct effect, i.e. the impact of aerosol-induced radiative warming on dynamics and clouds life cycle) has received increasing attention. Solmon et al. (2008) have investigated the climatic impact of shortwave and longwave radiative forcing of Saharan dust on the West African monsoon and Sahel precipitation using a regional climate model. They evidenced a reduction of monsoon intensity due to dust surface cooling, as well as an elevated heat pump effect in the higher troposphere induced by the dust diabatic warming. Heinold et al. (2008) have studied the mineral dust radiative effects and the feedbacks on the Saharan boundary layer meteorology by means of regional dust simulations for a one-week period in May 2006 using the regional dust model system LM-MUSCAT. They suggested that mineral dust modifies the stratification of the atmosphere and induce baroclinity. Saharan dust that crosses periodically the Atlantic between 1000 and $5000 \mathrm{~m}$ is also thought to play a role on the genesis and the evolution of tropical cyclones as suggested in recent studies (Dunion and Velden , 2004; Evan et al. , 2006).

Recently, Flamant et al. (2009) have investigated the structure of a dust plume travelling across West Africa with the African Easterly Jet (AEJ) during a major springtime dust event from the Bodélé region and Sudan using airborne lidar and dropsonde measurements, in June 2006. They hypothesized that the dust could impact on the radiation budget in the AEJ region and the structure of the AEJ itself (most notably via the aerosol semi-direct effect). Transport of massive amounts of dust in the AEJ from remote eastern sources such as the Bodélé depression in northern Chad or the sources in west Sudan could impact on the atmospheric stratification in the AEJ region and, in turn, modify the properties of the AEJ itself, thereby possibly modifying the West African weather at the synoptic scale.

The objective of the paper is to provide reliable estimates of the heating rate profiles at the regional scale (in both the short- and long-wave part of the spectrum) associated with the dust transported over the Sahel that can, in turn, be used to assess the impact of dust on the dynamic of the AEJ and African easterly waves. As a first step towards improved knowledge of the impact of the dust transported from the Saharan sources in the AEJ on the WAM dynamics, we aim at computing dust radiative heating rate over the Sahel and Sudanian (i.e. sub-Sahel) regions, using a combination of novel remote sensing measurements and a radiative code. Based on a similar approach, Raut and Chazette (2008) have shown the benefit of using high vertical resolution measurements from lidar to assess precise aerosol-related radiative forcing, especially in the case of multi-layered aerosol plume.

The present study is conducted on 13 and 14 June 2006 on a dust event observed over Benin and Niger which originated from the Bodélé depression and from West Sudan (Flamant et al., 2009). Dust-related heating rate profiles are computed for a variety of atmospheric and surface conditions using high spatial resolution lidar measurements acquired from both air- borne and space-borne platforms as well as the radiative code STREAMER (Key and Scheiger, 1998) in which we have implemented specific parameters representative of the area studied. This period was selected for several reasons: firstly, it occurred during a persistent large-scale transport episode of dust across West Africa (9-15 June 2006). Secondly, numerous airborne data (both in situ and remote sensing observations) were collected during the AMMA Special Observing Period (SOP, Lebel et al., 2010; June-September 2006). Thirdly, the airborne observations on 14 June were acquired at the time of and close to an A-Train overpass (including observations from the Cloud Aerosol Lidar and Infrared Pathfinder Satellite Observations - CALIPSO - among others, see Sect. 2).

This paper is divided into six sections. Observations and related instruments are presented in Sect. 2, as well as flight operation. We introduce in Sect. 3 the radiative code and the optical properties of dust used. Sect. 4 deals with the analysis of the case studies of 13 and 14 June 2006, including meteorological conditions in which data were taken. Radiative impact is analyzed and results are discussed in Sect. 5, before concluding in Sect. 6.

\section{Data sources}

\subsection{Ground-based observations}

We also use observations of aerosol single scattering albedo (SSA) and asymmetry factor $(g)$ at $441,674,869$ and $1018 \mathrm{~nm}$ derived from sun-photometer measurements acquired within the framework of the Aerosol Robotic Network (AERONET). The SSA is defined as the ratio of the scattering coefficient to the aerosol extinction coefficient (AEC). The parameter $g$ is defined as the intensity-weighted average cosine of the scattering angle (the angle between incident light and scattering direction). The value of $g$ ranges between -1 for entirely backscattered light to +1 for entirely forward scattered light. The level 2.0 (cloud-screened) data from stations distributed over the Sahelian region, namely Banizoumbou (Niger; $13.54^{\circ} \mathrm{N}, 2.66^{\circ} \mathrm{E}$ ), and the sub-Sahel, namely Djougou (Benin; $9.76^{\circ} \mathrm{N}, 1.6^{\circ} \mathrm{E}$ ) and Ilorin (Nigeria; $8.32^{\circ} \mathrm{N}, 4.34^{\circ} \mathrm{E}$ ) are used (see Fig. 1). Given that the AODs are larger than 0.5 at $440 \mathrm{~nm}$ in the present case, the uncertainty on the SSA is on the order of 0.03 (Dubovik et al., 2000).

The irradiance measurements obtained from three groundbased stations deployed during AMMA, namely Wankama (Niger, $13.65^{\circ} \mathrm{N}, 2.64^{\circ} \mathrm{E}$ ), Agoufou (Mali, $15.34^{\circ} \mathrm{N}$, $1.48^{\circ} \mathrm{E}$ ) and Nalohou (Benin, 9.73 $\mathrm{N}, 1.60^{\circ} \mathrm{E}$ ) have been used for direct comparison with the irradiances derived from the radiative model (see Sect. 3 for details). Only comparisons with the station of Wankama are presented in this paper. Downward and upward shortwave irradiances in Wankama were obtained from a Kipp and Zonen's CM3 

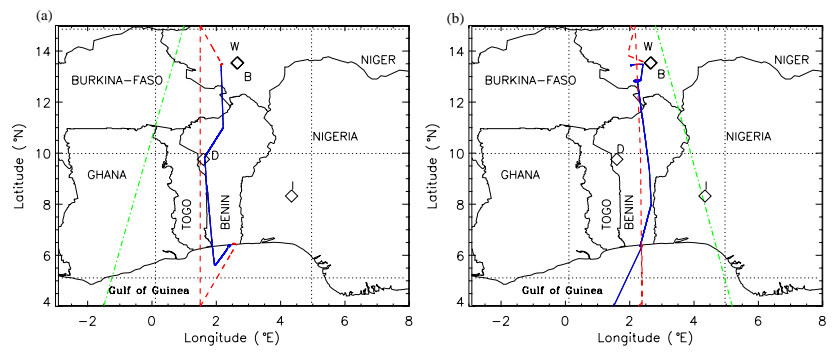

Fig. 1. SAFIRE F/F20 (red dashed line) and ATR-42 (solid blue line) flight on 13 June (a) and and 14 June (b) 2006. Overlain are the CALIPSO tracks (green dash-dotted lines) at 01:37 UTC on 13 June and 14:00 UTC on 14 June 2006. I, D, B and W correspond to the location of the Ilorin, Djougou, Banizoumbou AERONET stations and Wankama AMMA station, respectively.

ISO-class, thermopile pyranometer (spectral response: $0.3-$ $2.8 \mu \mathrm{m}$ ) while longwave irradiances were obtained from a CG3 pyronometer using a PT100 TRD sonde (spectral response: $5.0-50 \mu \mathrm{m})$.

\subsection{Airborne data}

During the AMMA SOP (Special Observing Period) 1a (June 2006, see Lebel et al., 2010), the Service des Avions Français Instrumentés pour la Recherche en Environnement (SAFIRE) operated two research aircrafts, namely the Falcon 20 (F/F20) and the ATR 42. On 13 June 2006, the two aircraft flew for a coordinated north south land-atmosphere-ocean interaction mission over Benin, between Niamey (Niger) and Cotonou (Benin). In the afternoon of 14 June 2006, the two aircrafts flew between Cotonou and Niamey.

The aerosol vertical distribution together with the atmospheric dynamics and thermodynamics properties were documented at the regional scale using the airborne lidar LEANDRE 2 (Bruneau et al., 2001; Flamant et al., 2007) and dropsonde measurements along the meridian transects performed at $1.5^{\circ} \mathrm{E}$ on 13 June and between $2.15^{\circ} \mathrm{E}$ and $2.5^{\circ} \mathrm{E}$ on 14 June, spanning from $15^{\circ} \mathrm{N}$ to $4^{\circ} \mathrm{N}$ (Fig. 1). The F/F20 was flying at $8000 \mathrm{~m}$ above mean sea level (m.s.l.). Operations were conducted between 1130 and 13:30 UTC, and 13:00 and 15:00 UTC, on 13 and 14 June, respectively. Twelve dropsondes were released on 13 June and one on 14 June. Dropsonde data were processed with the Atmospheric Sounding Processing Environment software.

LEANDRE-derived AEC profiles (at $730 \mathrm{~nm}$ ) were obtained from the total attenuated backscatter coefficient (TABC) profiles, via a standard lidar inversion technique (Fernald et al., 1972; Fernald , 1984), with a vertical resolution of $15 \mathrm{~m}$ and a horizontal resolution of roughly 500 $\mathrm{m}$. This inversion technique relies on the proportionality of the aerosol backscatter coefficient (ABC) and the AEC, i.e. $A B C(z)=B E R \times A E C(z), B E R$ being the aerosol backscatter-to-extinction ratio and $z$ the altitude. We con- sider that the BER is constant with altitude (e.g., Welton et al., 2000) and we use a value of $0.02 \mathrm{sr}^{-1}$, which is a climatological value for dust (Omar et al., 2009) interpolated lineary at $730 \mathrm{~nm}$ between values provided at $532 \mathrm{~nm}\left(0.024 \mathrm{sr}^{-1}\right)$ and $1064 \mathrm{~nm}\left(0.018 \mathrm{sr}^{-1}\right)$. The molecular backscatter coefficient profiles used in the inversion procedure were obtained from dropsonde-derived pressure and temperature measurements. In the lidar inversion, multiple scattering effects may be considered by introducing a so-called multiple scattering factor $\eta(0 \leq \eta \leq 1)$ to account for the reduction of the effective aerosol extinction coefficient $\eta A E C(z)$ (e.g., Nicolas et al., 1997). In the case of dust particles, this effect can be neglected $(\eta \approx 1)$ for airborne lidar measurements (Ackermann et al., 1999), since the volume of air sampled by the lidar beam is sufficiently small (note that the laser footprint on the ground is $\approx 3.5 \mathrm{~m}$ wide). Because of the uncertainties on the value of the BER, the sensitivity of dust-related heating rates will be conducted thereafter (see Sect. 5).

Downward and upward shortwave irradiances at the altitude of the aircraft were obtained from an Eppley PSP pyranometer (spectral response: $0.285-2.8 \mu \mathrm{m}$ ) while downward and upward longwave irradiances were obtained from an Eppley PIR pyrgeometer (spectral response: $4-45 \mu \mathrm{m}$ ). These measurements will be for direct comparison with the surface albedo and the irradiances derived from the radiative model (see section 3 for details).

The dust aerosol optical and radiative properties, as well as their vertical distribution were documented in situ in the lower troposphere using the AVIRAD aerosol sampling system (Formenti et al., 2010). It consists in an isoaxial and isokinetic inlet whose 50\% passing efficiency has been estimated at $9 \mu \mathrm{m}$ in diameter (Formenti et al., 2010). At the cruise speed of the ATR-42 $\left(100 \mathrm{~ms}^{-1}\right)$ the delivered flow rate is $350 \mathrm{Lm}^{-1}$. This allows connecting the inlet to multiple instruments in parallel. Seven straight sampling lines depart from the inlet to provide: (i) straight-levelled run averaged measurements of the particle absorption coefficient at 370, 470, 520, 590, 660, 880 and $950 \mathrm{~nm}$ (aethalometer model AE31, Magee Sci.), (ii) high-temporal resolution (1 s) measurements of the particle scattering and backscattering coefficients at 450,550 and $700 \mathrm{~nm}$ (nephelometer model 3596, TSI Inc.); (iii) number size distribution between 0.3 and $20 \mu \mathrm{m}$ in diameter (optical particle counter model 1.108, GRIMM), (iv) size-segregated aerosol composition and mass concentration by impactor sampling (4-stage Dekati impactors) and (v) bulk aerosol composition and mass concentration by on-line filter sampling on Nuclepore membranes. The in situ scattering and absorption coefficients and the number size distribution were used to (i) evaluate the relevance of the aerosol model used in the STREAMER radiative code (aerosol single scattering albedo and asymmetry factor), and (ii) to validate the lidar extinction coefficient retrievals performed for both LEANDRE 2 and CALIOP. State-of-theart correction factors were applied to the scattering, backscattering and absorption coefficient measurements (Anderson 


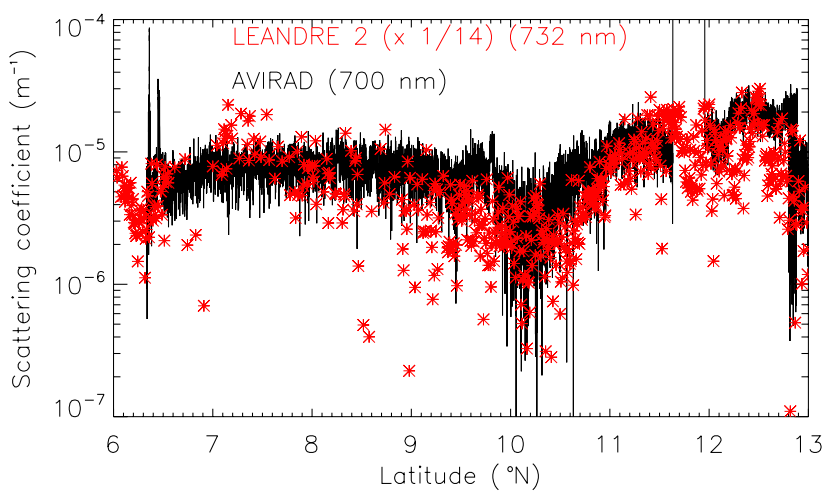

Fig. 2. Aerosol scattering coefficient at $730 \mathrm{~nm}$ derived from LEANDRE 2 (between 0 and $180^{\circ}$ ) at $700 \mathrm{~m} \mathrm{m.s.l.} \mathrm{(red} \mathrm{symbols)} \mathrm{and}$ aerosol scattering coefficient derivd from AVIRAD (between 90 and $180^{\circ}$ ) at $700 \mathrm{~nm}$ (black solid line). LEANDRE 2 data are divided by a factor of 14 with respect to the AVIRAD data (see text for details).

and Ogren , 1998; Weingartner et al., 2003). Size correction of GRIMM data depends on the effective aerosol refractive index, and can result in important modifications in the position of the size bins, in particular when the aerosol is absorbing (Collins , 2000). However, when this is not determined in a robust way, the correction itself can induce important errors. Nonetheless, we have performed Mie calculations using the refractive index estimated by Voltz (1973) and Grams et al. (1974) (also see Sect. 3) at $780 \mathrm{~nm}(1.53-0.008 \mathrm{i}$ and 1.53$0.0012 \mathrm{i}$, respectively) to calculate the correction factor to be applied to the GRIMM nominal diameters. The correction factor is important, up to a factor of 2 for particles larger than $4.5 \mu \mathrm{m}$ in diameter. As a consequence, the asymmetry parameter $g$ increases of $6 \%$ independently of the wavelength.

Only data collected during straight and leveled runs at constant altitudes above mean sea level were considered and north of $10^{\circ} \mathrm{N}$ ). In particular, the data used in this paper were collected whilst the aircraft was flying at $700 \mathrm{~m} . s .1$., that is, very close to the ground. Over the two entire straight and leveled runs considered in this paper the air flow through the instrument was $11.3 \pm 0.4 \mathrm{Lmin}^{-1}$ (13 June) and $10.7 \pm 0.1 \mathrm{Lmin}^{-1}$ (14 June). This variability has been taken into account when estimating the errors affecting the measurements.

On 13 and 14 June, the ATR42 flew patterns at a constant altitude of 700 m.s.l. (see Fig. 1), i.e. in the monsoon layer for the most part. It also performed two soundings, on both days and at both ends of the flight track (i.e. in the vicinity of Niamey and Cotonou), in which case it sampled the dust layer originating from the Bodélé depression as well as Western Sudan and subsequently transported with the AEJ across West Africa and over Benin.

Figure 2 shows a comparison between the LEANDREderived scattering coefficient (at $730 \mathrm{~nm}$ ) and the AVIRADderived scattering coefficient at $700 \mathrm{~nm}$ at an altitude of
$700 \mathrm{~m}$ m.s.l. For the comparison, the lidar-derived scattering coefficient is divided by a factor of 14 (the reason for this is explained below). The LEANDRE-derived scattering coefficient (between 0 and $180^{\circ}$ ) is computed as the product of the AEC by the SSA, after screening most cloudy profiles. The SSA value used here is derived from the AVIRAD observations along the legs of interest. By construction, the AVIRAD scattering coefficient is obtained between 90 and $180^{\circ}$. The ratio between the scattering coefficient between 0 and $180^{\circ}$ and the scattering coefficient between 90 and $180^{\circ}$ was computed using Mie theory for spherical particles based on AVIRAD observations and two dust aerosol models (described at length in Sect. 3). This ratio was found to be equal to 12 in one case and 16 in the other case, thereby yielding a value of $14 \pm 2$. Hence, the scattering coefficient derived from LEANDRE 2 is expected to be on the order of 14 times that derived from AVIRAD.

When modeling the aerosols as non spherical shapes rather than spherical particles, small differences were found between the results from the Mie model with spherical particles and Mishchenko T-matrix code (Mishchenko et al., 1996) using prolate and oblate particles uniformly distributed over all the possible aspect ratios centered around 1 (1\% error on the SSA and the extinction coefficient). Mishchenko et al. (1996) suggested that this phenomenon can occur when large numbers of randomly orientated particles in the sampling chamber are averaged, leading to a smaller error than for individual particle counting. It may be also due to the uncertainties in our measurements, especially of size distribution, and the lack of knowledge on dust morphology.

As shown in Fig. 2, the scattering coefficient derived from AVIRAD and from LEANDRE (divided by 14) exhibit similar fluctuations as a function of latitude, with a minimum between 10.1 and $10.3^{\circ}$ N. Provided that a reduction by a factor of 14 is applied to the lidar data to account for the different observation geometry of the instruments, a very good agreement is found in terms of the scattering coefficient obtained with LEANDRE 2 and AVIRAD. This is an indication of the coherence between the two datasets.

\subsection{Space-borne observations}

\subsubsection{Aerosol distribution}

The regional distribution of dust aerosols was described using three complementary satellite products. First, the Ozone Monitoring Instrument (OMI) daily Aerosol Index (AI) product was used. Second, aerosol optical depth (AOD) fields were obtained from the Moderate-resolution Imaging Spectroradiometer (MODIS) AQUA collection 005 over vegetated surfaces, and the MODIS/AQUA Deep Blue Collection 005 over desert surfaces (MOD08 product). Third, the vertical distribution of the aerosols was documented using the space-borne lidar CALIOP (Winker et al., 2007) onboard the CALIPSO satellite. The three instruments are embarked 
on platforms (namely AQUA, CALIPSO and AURA for MODIS, CALIOP and OMI, respectively) that are part of what is now commonly referred to as the A-Train, and view the same scene within a few minutes. The A-train orbit overpasses West Africa twice a day, once during the daytime (between 12:30 and 14:30 LST - local standard time) and once during the nighttime (between 00:30 and 02:30 LST), and has a revisit time period of the same orbit of 16 days (Stephens et al., 2002).

The lidar CALIOP provides vertical profiles of atmospheric reflectivity (at $532 \mathrm{~nm}$ and $1064 \mathrm{~nm}$ ) allowing the retrieval of the vertical distribution and the optical and radiative properties of aerosols and thin clouds. It has been previously used to study desert aerosols in the framework of AMMA program (e.g., Cuesta et al., 2008; Flamant et al., 2009; Kim et al., 2009). The CALIOP-derived reflectivity at $532 \mathrm{~nm}$ was analyzed along 2 overpasses (on 13 June around 01:39 UTC, 14 June around 13:20 UTC, see Fig. 1 for the position of the tracks).

We have computed CALIOP-derived AEC profiles (at $532 \mathrm{~nm}$ ) using a standard inversion procedure as described in Sect. 2.2, and CALIOP TABC profiles (level 1B version 2 products) with a vertical resolution of $60 \mathrm{~m}$ and a horizontal resolution of roughly $12 \mathrm{~km}$. The molecular backscatter coefficient profiles used in the inversion procedure were obtained from molecular density profiles extracted from the National Centers for Environmental predictions (NCEP) analyses along CALIPSO tracks. We use a constant BER profile with altitude yielding a value of $0.024 \mathrm{sr}^{-1}$ at $532 \mathrm{~nm}$ (Omar et al., 2009). Since the laser beam of CALIOP samples a rather large volume of air (the footprint at the ground is $90 \mathrm{~m}$ wide), we have to account for multiple scattering effects associated with dust $(\eta \leq 1)$. Following the Monte-Carlo simulations of Young et al. (2008) and Berthier et al. (2006), we used a $\eta$ profile increasing exponentially from 0.65 at the layer top, 0.87 below $500 \mathrm{~m}$ above ground level (a.g.l.) and to 0.95 at the ground, as in Cuesta et al. (2009) and Messager et al. (2010).

\subsubsection{Cloud properties}

The presence of clouds underneath an aerosol layer can significantly modify the heating rates due to aerosols. Johnson (2003) has shown that presence of absorbing aerosol in stratocumulus-capped boundary layers led to large positive semi-direct radiative forcing, opposite in sign to the conventional direct forcing. For cumulus conditions, the semidirect forcing was much smaller. Johnson et al. (2004) work on semi-direct effect of aerosol evidenced cooling at the top of the atmosphere whenever absorbing aerosol resided above the cloud layer. When aerosols were located at the same level as the cloud, Johnson et al. (2004) show that this resulted in a strong heating.

Hence, cloud properties are necessary to estimate the effect of clouds. MODIS-derived cloud properties were also used as input to the STREAMER radiative code in order to compute aerosol radiative heating rate above the shallow cumulus clouds commonly observed at the top of the monsoon layer over the southern half of Benin. The MODIS cloud product (MYD06 L2 collected from the AQUA platform) combines infrared and visible techniques to determine both physical and radiative cloud properties in the daytime as well as the nighttime. Daily global Level 2 data are used in this study, namely cloud phase (ice vs. water), effective droplet radius, and cloud optical thickness. These variables are available at $1-\mathrm{km}$ resolution. Cloud top temperature, height, effective emissivity and phase as well as cloud fraction are also used and available at 5-km resolution. For the sake of homogeneity, $1-\mathrm{km}$ resolution data were averaged to form $5 \times 5 \mathrm{~km}^{2}$ pixels.

\subsubsection{Earth surface characterization}

The radiative heating rate of aerosols depends on the reflectivity of the underlying surface as shown in Bierwirth et al. (2009). As the albedo can vary significantly along a given track (ranging from 0.2 near the Gulf of Guinea coast region to almost 0.4 over parts of the Sahara), the evolution of the MODIS-derived albedo along the F/F20 and CALIPSO tracks was taken into account for the computation of the aerosol radiative heating rate profiles. In addition to the AOD and cloud properties related products, MODIS-derived surface albedo retrievals were also used in this study as input to the STREAMER radiative code. The MODIS albedo products (MCD43C3) used in this paper are the directional hemispherical reflectance (black-sky albedo) and bihemispherical reflectance (white-sky albedo). The MCD43C3 product contains 16 days of data provided in a level-3 data set projected to a $0.05^{\circ} \times 0.05^{\circ}$ grid. Both Terra and Aqua data are used to obtain this product, providing the highest probability for quality input data. The average of the black-sky albedo and white-sky albedo is provided as an input to STREAMER. The standard deviation on the albedo corresponding to the area of interest is about 0.025 .

Figure 3 shows a comparison of the MODIS surface albedo with the surface albedo determined from the airborne pyranometers onboard the F/F20 as the ratio of the upward to the downward shortwave irradiances on 14 June. A very good agreement between the two is observed north of $9.5^{\circ} \mathrm{N}$. South of $9.5^{\circ} \mathrm{N}$, the differences are related to the presence of cumulus type clouds at the top of the monsoon layer that can be observed in the airborne irradiances, while the MODIS albedo is derived from cloud-screened scenes. It is worth noting, that the albedo of cumulus clouds never exceeds 0.4 , as inferred from the airborne measurements. 


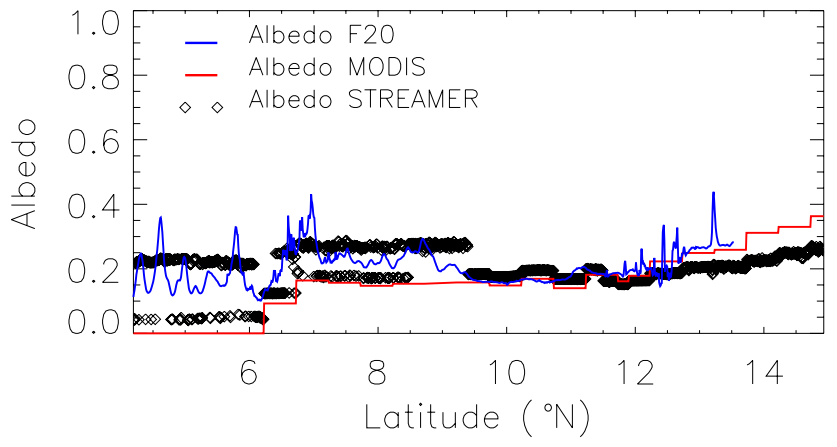

Fig. 3. Surface shortwave albedo from MODIS (red line) derived along the F/F20 flight track on 14 June 2006. Superimposed are the total effective albedo (accounting for the surface, aerosol and clouds) obtained from shortwave downwelling and upwelling airborne irradiances (blue line) and from STREAMER-simulated irradiances (dark diamonds).

\section{The radiative code}

Vertical profiles of aerosol radiative heating rate over West Africa are quantied using the radiative transfer code STREAMER (Key and Scheiger, 1998; Key et al., 1998). STREAMER is a flexible code developed to compile radiances or irradiances for various atmospheric and surface conditions. Calculations are made using a 2 stream scheme with a discrete ordinate (DISORT) solver. Upward and downward irradiances (i.e. shortwave, longwave and net irradiances, see Eq. 1), cloud radiative effect (cloud forcing), and heating rates (HRs) can be computed over 24 shortwave bands ( 0.28 to $4 \mu \mathrm{m}$ ) and 105 longwave bands ( 4 to $400 \mu \mathrm{m}$ ).

The net irradiance can be written as:

$F_{z}=F_{\mathrm{dir}, z}^{\downarrow}+F_{\mathrm{diff}, z}^{\downarrow}-F_{\mathrm{diff}, z}^{\uparrow}-F_{\mathrm{em}, z}^{\uparrow}$

where $F_{\mathrm{dir}, z}^{\downarrow}$ is the direct downward irradiance, $F_{\mathrm{diff}, z}^{\downarrow}$ is the diffuse downward irradiance, $F_{\text {diff, } z}^{\uparrow}$ is the diffuse upward irradiance, $F_{e m, z}^{\uparrow}$ is the upward emitted irradiance and $\mathrm{z}$ is the altitude.

In the present study, the radiative forcing (i.e. heating or cooling) is calculated from a pair of STREAMER simulations, i.e. as the difference between a dust-laden and a dustfree simulation (see Eq. 2). The total radiative forcing in the shortwave (longwave) part of the spectrum is computed as the integral of the forcing over the 24 (105) bands.

The radiative forcing is given by:

$\Delta F=F_{d, z}-F_{o, z}$

where $F_{d, z}$ and $F_{o, z}$ are the net irradiance in the presence of dust and without dust, respectively.
Heating/cooling rates are computed for each layer, and are based on finite difference estimates of the irradiance divergence at each pair of levels (Eq. 3):

$\frac{\Delta T}{\Delta t}=-\frac{g}{C_{p}} \frac{\Delta F}{\Delta p}$

where $T$ is temperature $(\mathrm{K}), t$ is time (s), $g$ is gravitational acceleration $\left(\mathrm{ms}^{-2}\right), C_{p}$ is the specific heat of dry air $\left(\mathrm{J} \mathrm{K}^{-1}\right.$ $\left.\mathrm{kg}^{-1}\right), F$ is the net all-wave flux ( $\mathrm{W} \mathrm{m}^{-2}$ ), and $\mathrm{p}$ is the pressure $(\mathrm{Pa})$. The gravitational acceleration is computed for each level from an empirical relationship derived for a standard atmosphere. Computations are begun at the top of the atmosphere. Layer heating/cooling rates are converted to degrees per day and are listed with the level that is their top. Therefore the surface level has a value of zero.

The aerosol optical properties (SSA, $g$ and the AEC) can be user defined. These parameters (especially the SSA) are critical, and one should note that these parameters are very sensitive to the mineral composition of dust and size distribution (Sokolik and Toon, 1999) and need adjustment to retrieve representative forcings (Balkanski et al., 2007). We have considered here two aerosol models in order to provide an estimate of the dispersion associated with the heating rate retrievals depending on the chosen aerosol model (see section 5.2). The models of SSA and $g$ were selected for their overall agreement with the data available on this case (airborne data and sun-photometers) in the visible. They are specified as a function of wavelength (Fig. 4).

The first dust model corresponds to the dust model prescribed in STREAMER, but modified following the study of Raut and Chazette (2008) in the visible part of the spectrum (between 0.2 and $0.7 \mu \mathrm{m}$ ) to account for the ultra-violetvisible complex refractive index of dust particles observed in this part of Africa. This was determined from lidar measurements onboard an ultra light aircraft and the AERONET sunphotometer-derived size distributions gathered in Niamey during AMMA (January-February 2006). In this model, the SSA, the asymmetry parameter and the AEC between 0.7 and $40 \mu \mathrm{m}$ are prescribed according to the aerosol complex refractive index published by Voltz (1973). This model is here on referred to as the RaCH model. The second model chosen is the more general Alfaro I model detailed in Chomette (1999) and Alfaro et al. (1998). Chomette (1999) derived the asymmetry parameter, SSA and AEC using a Mie model for spherical particles based on the refractive index of Voltz (1973) in the infrared (0.7 to $40 \mu \mathrm{m})$ and that of Grams et al. (1974) in the visible $(0.2$ to $0.7 \mu \mathrm{m})$. This model is referred to as the CHOM model in the following. Observations used in model $\mathrm{RaCH}$ have been made during the winter season, and aerosol properties may then be different from the ones observed in summer, as their origin may not be the same. The two selected models correspond to different compositions which are expected to induce a difference larger than the real one. 

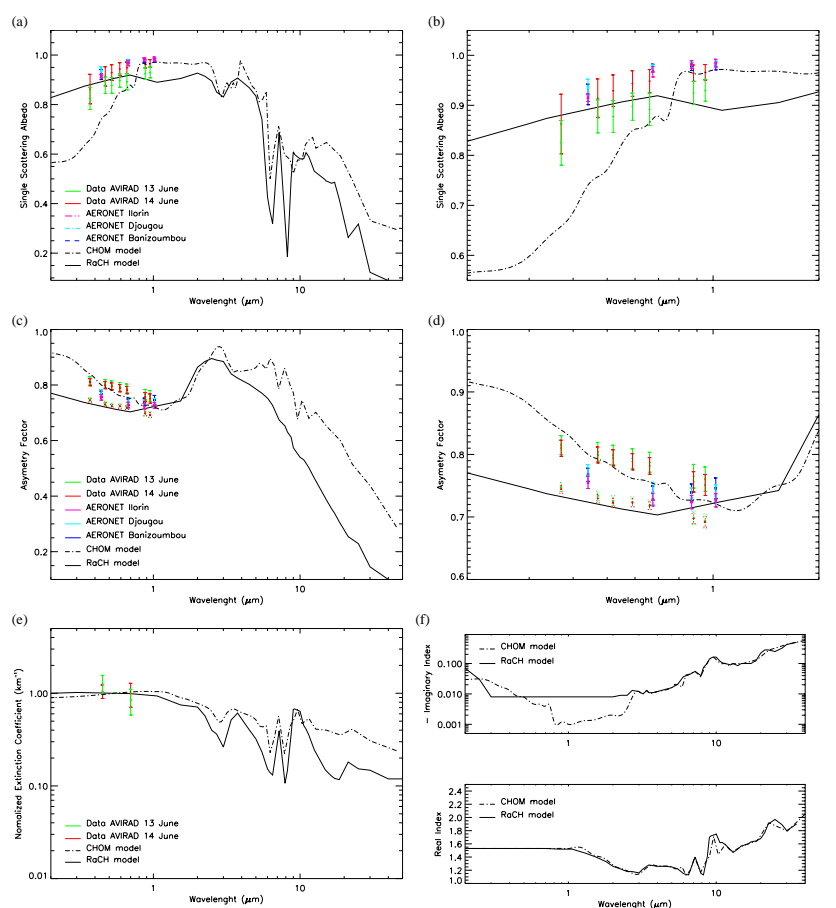

Fig. 4. Aerosol optical properties from the $\mathrm{RaCH}$ model (black solid line) and CHOM model (black dashed line) as a function of wavelength: single scattering albedo (a), asymetric factor (c), extinction coefficient normalized at $550 \mathrm{~nm}$ (e) and refractive index (f) used for STREAMER. The red and green symbols correspond to the measurements made by the AVIRAD aerosol sampling device during the 13 and 14 June 2006 ATR-42 flights. AERONET retrievals are in purple (Ilorin), light blue (Djougou) and dark blue (Banizoumbou). (b) as in (a) but zoomed between 0.2 and $2 \mu \mathrm{m}$. (d) as in (c) but zoomed between 0.2 and $2 \mu \mathrm{m}$.

The single scattering albedo from the CHOM is seen to be greater (lower) with respect to the $\mathrm{RaCH}$ model at wavelength greater (lower) than $0.7 \mu \mathrm{m}$ (Fig. 4a, b). From Fig. 4b it is obvious that sun-photometer data are in better agreement with the $\mathrm{RaCH}$ model (resp. the CHOM model) for wavelength shorter (resp. larger) than $0.7 \mu \mathrm{m}$, thereby indicating the weakly absorbing nature of the dust aerosols sampled over the AERONET sites in Niger, Benin and Nigeria. The columnar SSAs derived from AERONET are ranging from 0.91 at $441 \mathrm{~nm}$ to 0.98 at $1018 \mathrm{~nm}$. The AVIRAD derived SSA values exhibit more dispersion than their sunphotometer counterparts, especially on 14 June 2006. On 13 June, airborne SSA values are around 0.83 , evidencing the presence of weakly absorbing aerosols. On 14 June, SSA values are greater and exhibit a larger dispersion than on 13 June. It is worth noting that AVIRAD-derived SSA values are consistently showing better agreement with the model exhibiting the largest SSA. In conclusion, it appears that the aerosols in $\mathrm{RaCH}$ are likely too absorbing across the visible spectrum. Likewise, the aerosols in CHOM are too absorbing below $0.8 \mu \mathrm{m}$ and are in good agreement with observations between 0.8 and $1.1 \mu \mathrm{m}$.

The asymmetry factor from the two models is found in broad agreement between 1 and $2 \mu \mathrm{m}$, while it is seen to be underestimated in the $\mathrm{RaCH}$ model with respect to the CHOM model for the remaining part of the spectrum considered here (Fig. 4c, d). Between 0.3 and $1 \mu \mathrm{m}$, the sunphotometer derived asymmetry factor values are between the curves associated with the two models (Fig. 4d). Two series of asymmetry factor values were obtained from the AVIRAD data, based on the refractive index of the two models at $780 \mu \mathrm{m}$ (see Sect. 2). AVIRAD-derived observations are found in good agreement with the asymmetry factor of both models. Little difference was observed between asymmetry factor values on 13 and 14 June, for a given model. They range between 0.72 and 0.82 , in agreement with the values of Saha et al. (2008) and Raut and Chazette (2008).

Figure $4 \mathrm{e}$ shows the spectral evolution of the modeled AEC (normalized at $550 \mathrm{~nm}$ ), together with the AVIRAD measurements available in the visible. The normalized AEC in the $\mathrm{RaCH}$ model is underestimated (overestimated) with respect to the CHOM model for wavelengths larger (smaller) than $550 \mathrm{~nm}$. AVIRAD data are in broad agreement with the modeled AEC. Finally, the real refractive indices used in $\mathrm{RaCH}$ and $\mathrm{CHOM}$ are very similar but imaginary parts are not, reflecting SSA differences (Fig. 4f).

Gaseous absorption by water vapour, carbon dioxide, ozone, and oxygen is computed following Tsay et al. (1989). The model runs with an emissivity of 0.90 for desert surfaces (Ogawa et al., 2004) and of 0.85 for the oceanic surfaces. The spectral reflectance is taken according to Tanre et al. (1986) for desert and from Briegleb et al. (1986) for oceanic surfaces. Profiles of atmospheric temperature, water vapor, and pressure need to be prescribed as inputs to the STREAMER simulations.

For the surface albedo a built-in spectral albedo model prescribed in STREAMER is used, but it is scaled by a userspecified visible albedo determined using MODIS data for the surface types present. The surface albedo models available in SREAMER are based on either modeled or observed data in the literature. Sand data are from Tanre et al. (1986). Spectral albedos for grass, dry grass and deciduous forest were taken from the ASTER Spectral Library v1.0 CD (California Institute of Technology, 1988).

\section{The 13-14 June 2006 case study}

\subsection{Synoptic conditions during the dust event}

During the 9-12 June period, i.e. 2-4 days before the airborne observations over Benin, strong northeasterly Harmattan winds were seen in the European Centre for Mediumrange Weather Forecast (ECMWF) analyses over the NigerChad-Sudan sector of the Sahara (not shown). These winds 
were the primary driver of dust emission in this sector, known to hold some of the most productive dust sources in West Africa, notably the Bodélé depression (in Chad) and the $\mathrm{Su}$ danese sources in the May-July period. The ECMWF analyses at $925 \mathrm{hPa}$ show strong winds, in the form of a northeasterly low-level jet, to the east of West Sudan at 00:00 UTC during the 9-13 June period (Flamant et al., 2009). Similarly, strong north-easterly low level winds were also observed between the Tibesti and Ennedi mountains in Chad, and over the Bodélé depression at 00:00 UTC. It is now well established that dust emission from the Bodele (and also over Sudan in this case) are related to the downward transfer of momentum from the nocturnal low-level jet to the surface due to turbulent mixing after solar heating commences each day (Todd et al., 2008).

The transport patterns of dust from eastern Saharan sources towards the southwest in this case have been described by Flamant et al. (2009). In particular, they have highlighted the role of the inter-tropical discontinuity and the Darfur Mountains in injecting the aerosols from Bodélé and Sudan, respectively, over the monsoon flow, and in the AEJ region.

\subsection{Regional distribution of aerosol from 9 to 13 June 2006}

The temporal evolution of the dust load over the Bodélé region and over Sudan has been investigated by Flamant et al. (2009) using daily MODIS Deep Blue AODs between 9 June and 15 June 2006. They show that over the Bodélé region, the dust load exhibited a decrease from 2.6 to 0.65 between 9 and 13 June, while over Sudan the dust load increased between 9 and 12 June (from 0.70 to 1.1), and decreased afterward. As noted by Flamant et al. (2009), the aerosol load appears to be advected westward between 9 and 14 June (not shown).

Figure 5a shows the regional distribution of AOD on 13 June. The dust transport from the Eastern dust sources across West Africa with the AEJ is seen in the form of an elongated band of high AOD values ( $>1$ at $550 \mathrm{~nm}$ ) extending from Sudan to Senegal between roughly $5^{\circ} \mathrm{N}$ and $18^{\circ} \mathrm{N}$. The dust load over Benin on 14 June (0.5-1.2) was observed to be smaller than on 13 June (1.5-1.6) (Fig. 5b). This is in agreement with Flamant et al. (2009) who have shown that in Djougou, AERONET-derived AOD values at $440 \mathrm{~nm}$ $(675 \mathrm{~nm})$ decreased from $1.12(1.06)$ at midday on 13 June to $0.72(0.66)$ at midday on 14 June.

\subsection{Vertical distribution of dust over Benin on 13 and 14 June}

The two-dimension cross-sections of TABC (AEC) retrieved from LEANDRE 2 along the F/F20 flight track on 13 June and 14 June are shown in Fig. 6a and c (Fig. $6 \mathrm{~b}$ and d), respectively.

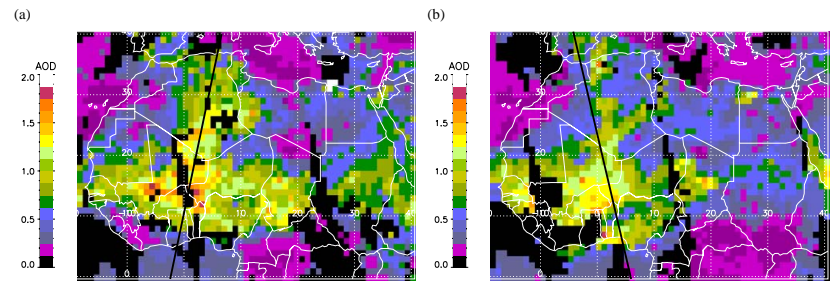

Fig. 5. MODIS-derived AOD at $670 \mathrm{~nm}$ over West Africa from 13 June (a) to 14 June (b) 2006 with CALIPSO tracks (black line).

On 13 June, LEANDRE 2 measurements evidenced the presence of an extended and thick dust plume spanning from north of Niamey $\left(15^{\circ} \mathrm{N}\right)$ to the Benin coastline $\left(6^{\circ} \mathrm{N}\right)$ (Fig. 6b). The depth of the plume was of the order of $3 \mathrm{~km}$, while the height of the top of the plume was observed to increase with latitude. In connection with the presence of the monsoon flow, smaller reflectivity values were observed below the dust plume along the entire transect, because of the much lower aerosol content to which the lidar is sensitive. South of $11^{\circ} \mathrm{N}$, over the continent, cumulus clouds were observed below the dust plume which marked the top of the monsoon layer. They are characterized by large AEC values, in excess of $0.5 \mathrm{~km}^{-1}$ In some instances, these clouds were observed to penetrate the dust plume (e.g. between $8^{\circ}$ and $9^{\circ} \mathrm{N}$ ). The dust plume over Benin and Niger is characterized by values in excess of $0.15 \mathrm{~km}^{-1}$. Values larger than $0.4 \mathrm{~km}^{-1}$ are also seen in the vicinity of Niamey (from 12.5 to $15^{\circ} \mathrm{N}$ ), between 2.5 and $3.5 \mathrm{~km}$ m.s.l.

On 14 June, north of $6.5^{\circ} \mathrm{N}$, the LEANDRE 2-derived AEC along the transect exhibits lower values than on the previous day above the monsoon flow (Fig. 6d). The largest AEC values on this day are on the order of $0.15 \mathrm{~km}^{-1}$. The latitudinal structure of the altitude of the plume top on 14 June was very similar to that observed on 13 June. However, it was observed to extent further south. Also, north of $10^{\circ} \mathrm{N}$, the AEC was observed to exhibit much less vertical variability. Numerous cumulus clouds were also observed at the top of the monsoon layer over the southern part of the transect. As pointed out by Flamant et al. (2009), the reduction of the dust load between 13 and 14 June is essentially related to the fluctuations of the dust emissions over the source regions 2 to 4 days prior to the airborne measurements over Niger and Benin. The comparison between the LEANDREderived AODs (obtained after integration of the AEC in the dust plume using a BER of $0.20 \mathrm{sr}^{-1}$ ) and the MODIS AODs at $670 \mathrm{~nm}$ along the F/F20 track the 14 June 2006, without clouds, is shown in Fig. 5e. MODIS AODs are consistent with lidar AODs in the plume. It is observed that the latitudinal trend in MODIS AODs is more marked to the South. The lower lidar AODs are partly explained by the larger wavelength. 

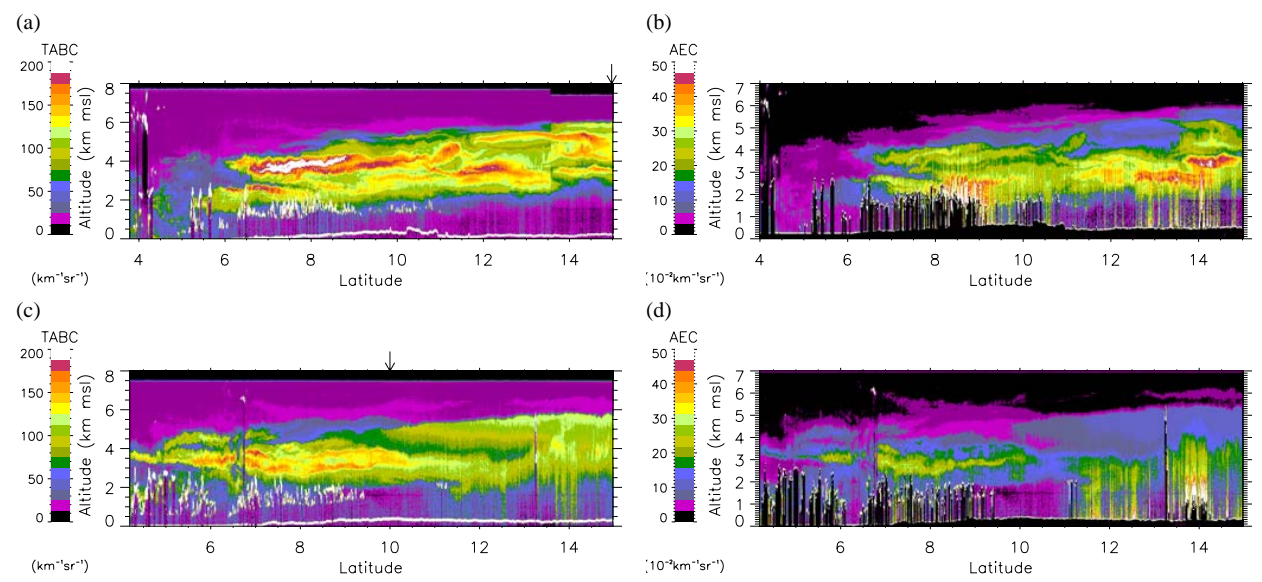

(e)

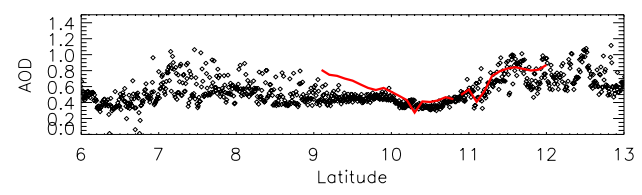

Fig. 6. LEANDRE-derived total attenuated backscatter coefficient (TABC) and LEANDRE-derived aerosol extinction (AEC) on 13 June (a and $\mathbf{b}$, respectively) and 14 June (c and $\mathbf{d}$, respectively). Clouds appear as areas with high TABC (white) above regions characterized by reduced TABC (blanks in AEC) as a result of attenuation between the cloud top and ground. (e) Aerosol optical depth from LEANDRE 2 at $730 \mathrm{~nm}$ (diamonds) and MODIS at $670 \mathrm{~nm}$ (solid red line).

\section{Radiative impact}

A series of STREAMER simulations were performed on 13 and 14 June 2006, to quantify radiative forcing profiles of dust aerosols according to the latitude (between $6^{\circ} \mathrm{N}$ to $15^{\circ} \mathrm{N}$ ) between the vegetated coast and the dry Sahel. HRs were computed indifferently in cloud-free conditions and in the presence of low-level clouds, in spite of the fact that STREAMER might not be able to account for threedimensional effects induced by clouds. This choice was motivated by the fact that the liquid water content associated with the cumulus clouds was rather small (on the order of $0.05 \mathrm{gm}^{-3}$, see below) and that the albedo associated with these clouds is comprised between 0.2 and 0.4 (Fig. 3). U1timately, the relevance of this approach was assessed by the fact that, at a given altitude, coherent HRs were obtained for contiguous profiles, independently of the presence of cumulus type clouds.

First, STREAMER simulations are performed for each airborne and space-borne lidar-derived AEC profile to infer the radiative forcing (i.e. heating or cooling) associated with the dust-laden atmosphere. In addition to the lidar-derived AEC profiles, profiles of temperature, pressure and water vapour mixing ratio as well as surface albedo have to be provided. MODIS-derived surface albedo $\left(0.05^{\circ}\right.$ resolution) was linearly interpolated along the F/F20 and CALIPSO tracks so that one albedo value is associated with a given AEC. In the case of the presence of a low-level clouds, such as the cumulus clouds seen in the lidar observations at the top of the monsoon layer (Fig. 6), the radiative forcing is computed at the level of the cloud layer and above the cloud top height, accounting for the cloud properties as derived from MODIS (see Sect. 2.3.2). We have used average cloud properties as representative of cumuli over southern Benin. The following MODIS-derived values have been used as characteristic of the cloud properties in the region of interest: the cloud optical thickness in the visible is taken as $7.25( \pm 6.63)$, the cloud particle effective radius is set to $7.74( \pm 3.80) \mu \mathrm{m}$ and the liquid water concentration is equal to $0.051( \pm 0.045)$ $\mathrm{gm}^{-3}$. We only consider low-level liquid-water clouds (highlevel or even mid-level clouds being almost always above the aerosol plume). The cloud top temperature is determined from the MODIS-derived cloud top pressure and a prescribed temperature profile. The cloud thickness is computed in STREAMER using the values of optical thickness, effective radius and water concentration. In the case of elevated clouds such as towering cumuli reaching the top of the aerosol layer (see for instance at $13.3^{\circ} \mathrm{N}$ in Fig. 6a and b) the profile is discarded altogether. There are very few such cases in the LEANDRE 2 data. Similarly, elevated clouds (such as cirrus clouds) associated with nearby convective systems were often observed with CALIPSO. In the cases also, the contaminated profiles are discarded altogether. Finally, the profiles of temperature, pressure and water vapour mixing ratio 

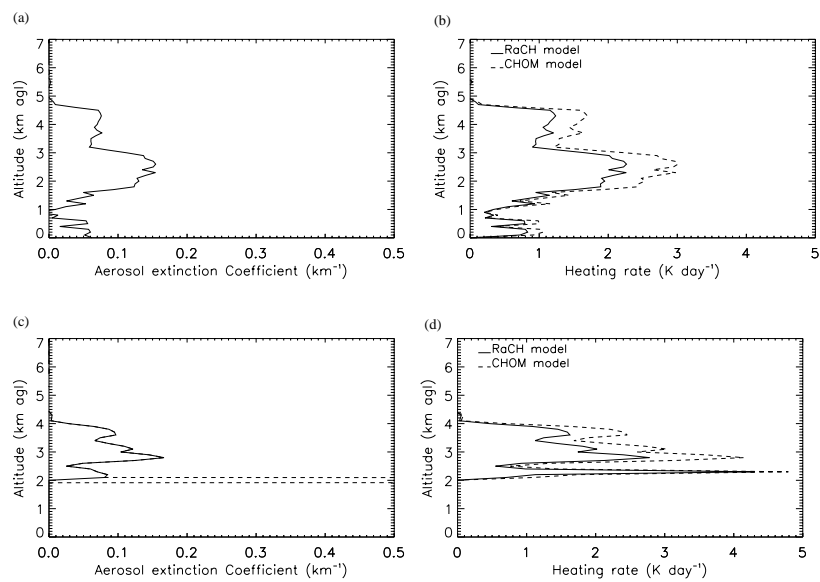

Fig. 7. LEANDRE-derived AEC profiles at $10^{\circ} \mathrm{N}$ (a) in cloud-free conditions and $5^{\circ} \mathrm{N}$ (c) in cloudy conditions, and corresponding heating rate $(\mathrm{HR})(\mathbf{b}, \mathbf{d})$ for the 14 June. Dashed line in (c) corresponds to location of the cloud top as derived from LEANDRE 2 measurements.

profiles needed to compute the radiative forcing from the CALIOP data are from NCEP analyses and are provided for each CALIOP profile. On the other hand, we have used dropsonde measurements to characterize the lower troposphere and compute the radiative forcing. STREAMER simulations on 13 June are performed using average temperature, pressure and water vapour mixing ratio profiles computed from the profiles obtained from the 13 dropsondes released on that day. STREAMER simulations on 14 June are performed using the temperature, pressure and water vapour mixing ratio profiles obtained from the single dropsonde released on that day. As discussed in the next section, radiative forcing in these cases was only marginally sensitive to the temperature, pressure and water vapour mixing ratio profiles.

Figure 7 shows an example of an AEC retrieved from the LEANDRE 2 measurements in cloud-free conditions over Benin at $10^{\circ} \mathrm{N}$ (Fig. 7a) and the corresponding vertical profile of radiative heating obtained from STREAMER using the $\mathrm{RaCH}$ model and CHOM model (Fig. 7b). In this example, the dust layer traveling the AEJ region is essentially comprised between 1.8 and $4.8 \mathrm{~km}$ a.g.l. Below, the AEC decreases and is minimum around $1 \mathrm{~km}$ a.g.l., and increases in the monsoon layer. Furthermore, the examination of the spectral dependence of the in situ measured scattering coefficient show that mineral dust was indeed dominant north of $10^{\circ} \mathrm{N}$. Figure 7 also shows an example of an AEC profile retrieved from LEANDRE 2 in the presence of lowlevel clouds over the Gulf of Guinea at $5^{\circ} \mathrm{N}$ (Fig. 7c) and the corresponding vertical profile of radiative heating obtained from STREAMER using the $\mathrm{RaCH}$ model and CHOM model (Fig. 7d). In the present case the altitude of cloud is $2.3 \mathrm{~km}$ m.s.l..
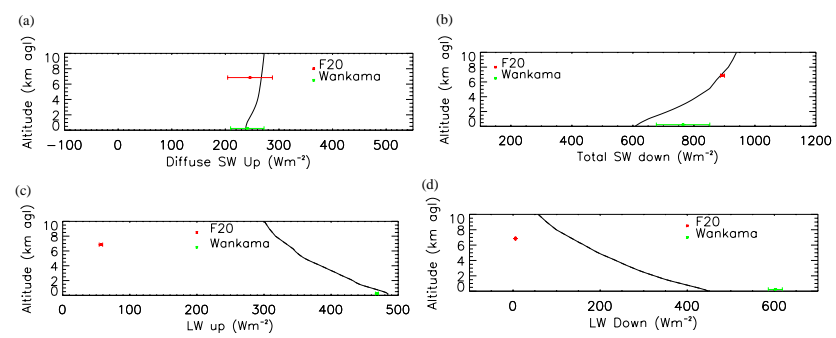

Fig. 8. Comparison between irradiances profiles derived from STREAMER (black solid line) obtained at the location of the Wankama station and at the time of the F/F20 overpass on 14 June. The data from the F/F20 are in red and data from the Wankama station are in green: upward shortwave (a) downward shortwave (b), upward longwave (c) and downward longwave (d).

The AEC profile shown in Fig. 7a was obtained using a BER of $0.02 \mathrm{sr}^{-1}$, and the heating rate profiles (Fig. 7b) were obtained using a visible surface albedo of 0.20 , a temperature profile derived from the dropsonde released on 13 June at $10^{\circ} \mathrm{N}$, a mean ozone column of 320 Dobson, and over a vegetated surface. This profile is referred to as the reference profile in the following. The maximum heating rate of about $2.3 \mathrm{Kday}^{-1}$ is obtained at the altitude where the dust plume exhibits the largest $\mathrm{AEC}$ values (i.e $3 \mathrm{~km}$ m.s.l.) for $\mathrm{RaCH}$ model and about $3 \mathrm{Kday}^{-1}$ with CHOM model. Satheesh et al. (2002) evidenced a dust-related heating rate between 0.4 and $1.2 \mathrm{Kday}^{-1}$ over northern Africa $\left(10-20^{\circ} \mathrm{N} ; 20-30^{\circ} \mathrm{E}\right)$ and southern Africa $\left(10-20^{\circ} \mathrm{S} ; 20-30^{\circ} \mathrm{E}\right)$ using direct observation of solar radiation in the shortwave part of the spectrum. From Fig. 7a and b, it is quite obvious that the heating rate increases as AEC increases, even in the monsoon layer.

The AEC profile shown in Fig. 7c was obtained using a BER of $0.02 \mathrm{sr}^{-1}$, and the heating rate profiles (Fig. 7d) were obtained using a cloud optical thickness in the visible of 7.25, a cloud physical thickness of $45 \mathrm{~m}$, a cloud particle effective radius of $7.74 \mu \mathrm{m}$, a liquid water concentration equal to $0.051 \mathrm{~g} \mathrm{~m}^{-3}$, a temperature profile derived from the dropsonde released on 13 June at $10^{\circ} \mathrm{N}$, and a mean ozone column of 320 Dobson. This profile is referred to as the reference profile in cloudy conditions in the following. In these conditions, the heating rate just above the cloud layer can reach $4.3 \mathrm{Kday}^{-1}$ ( $\mathrm{RaCH}$ model) and $4.8 \mathrm{Kday}^{-1}$ (CHOM model) for an AEC of $0.08 \mathrm{~km}^{-1}$, while lower heating values are obtained in cloud-free conditions at higher altitude where the AEC reaches $0.17 \mathrm{~km}^{-1}\left(2.8\right.$ and $3.2 \mathrm{Kday}^{-1}$ for the $\mathrm{RaCH}$ and CHOM models, respectively). This is found in agreement with the large-eddy model based results of Johnson et al. (2004) who evidenced the strongest heating rates to be located in the vicinity of clouds. In the case, nonlinear effects are evident in the immediate vicinity of the clouds, and the strongest heating rates are obtained for significant but yet moderate AEC values. 


\subsection{Comparison of irradiances and surface/cloud albedo from the model with measurements}

To assess the performance of STREAMER, a comparison was made between irradiances obtained at the location of the Wankama station and at the time of the F/F20 overpass on 14 June. The upward and downward shortwave and longwave irradiances profiles obtained from the LEANDRE 2 data using STREAMER are compared to near surface irradiance values (Wankama station) and irradiance values at the altitude of the F/F20 (Fig. 8). The instruments have similar spectral responses as described in Sect. 2, which are also close to longwave and shortwave spectral intervals defined in STREAMER (see Sect. 3). The comparison was conducted for diffuse upward shortwave irradiances (Fig. 8a), total downward shortwave irradiances (Fig. 8b), upward longwave irradiances (Fig. 8c) and downward longwave irradiances (Fig. 8d).

In the shortwave spectrum, a good agreement is seen between simulations and observations, exception made of the near surface total shortwave irradiance (Fig. 8b). In the longwave spectrum, the agreement between the STREAMER simulations and the observations are not as good, exception made of the near surface upward irradiances (Fig. 8d).

The surface/cloud albedo computed with STREAMER from each LEANDRE 2 profiles along the F/F20 track on 14 June is shown in Fig. 3. In cloud-free conditions, good agreement is found with MODIS surface albedo, as expected, since STREAMER uses a built-in albedo model scaled to MODIS visible albedo. Good agreement is also found with the albedo derived from airborne measurements. In the presence of cumulus type clouds, good agreement is found between STREAMER simulations and the albedo derived from airborne measurements, particularly between 6 and $9.5^{\circ} \mathrm{N}$ (i.e. over land).

\subsection{Sensitivity studies}

In this section we conduct a series of sensitivity studies to (i) the surface albedo, (ii) type of soil (vegetated or rather dry), (iii) aerosol backscatter-to-extinction ratio, (iv) ozone content, (iv) temperature and water vapor mixing ratio profiles, as well as (v) cloud microphysical, optical and structural properties, in order to evaluate the potential sources of uncertainties in the radiative forcing results presented above. The sensitivity analyses are conducted using the AEC profiles shown in Fig. 7a (cloud-free conditions) and Fig. 7c (lowlevel cloud conditions), and for the $\mathrm{RaCH}$ aerosol model. The sensitivity is also quantified in terms of uncertainty profiles (in $\mathrm{Kday}^{-1}$ ), which are computed as the difference between the reference profile (shown in Fig. $7 b$ and d) and sensitivity profile.
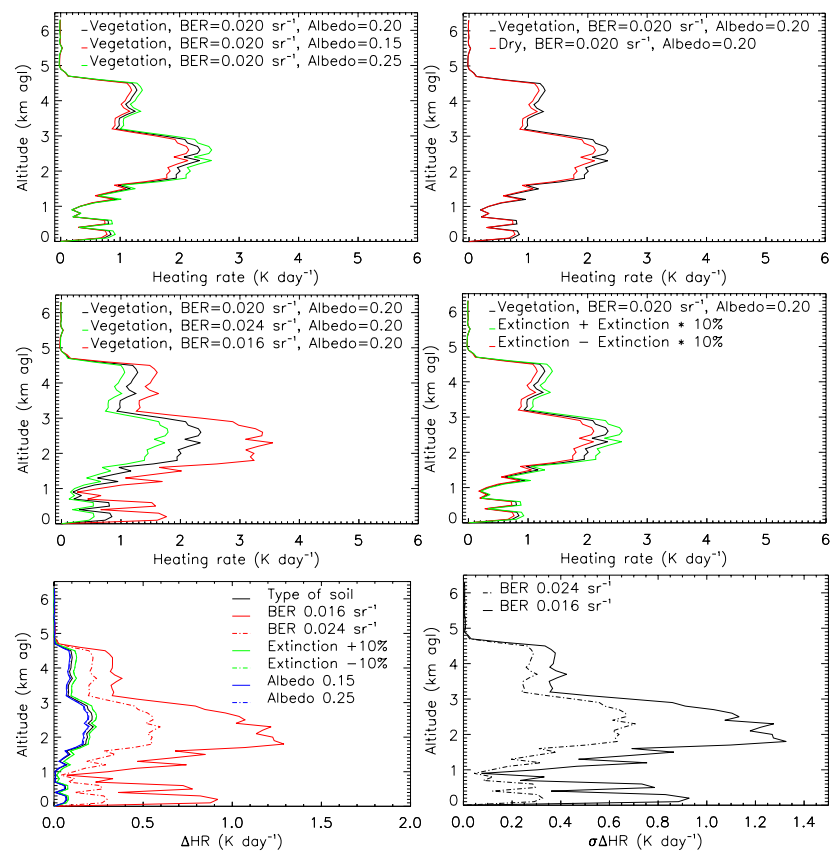

Fig. 9. Sensitivity of the LEANDRE-derived heating rate profile at $10^{\circ} \mathrm{N}$ on 14 June to: (a) surface albedo (b) type of soil, (c) dust BER and (d) lidar AEC. Uncertainties (in $\mathrm{Kday}^{-1}$ ) for each of the previous variables are shown in (e). Uncertainties are computed with respect to reference profile shown in Fig. 7a and using the $\mathrm{RaCH}$ model. The total uncertainty on the HR, taken as the sum of the quadratic errors of all variable previously shown are shown in (f): the dashed line corresponds to the minimum total uncertainty and the solid line corresponds to the maximum total uncertainty (see text for details).

\subsubsection{Cloud-free conditions}

The first sensitivity test was conducted on surface albedo. The MODIS albedo error is estimated to be on the order 0.03 (Roman et al., 2010). As shown by Fig. 3, a maximum albedo variability of 0.05 is observed per $0.5^{\circ}$ in latitude. So three values of surface albedo have been used to test the sensitivity of HRs to albedo: 0.20 (reference profile), 0.15 and 0.25 . While changing the albedo from 0.15 to 0.25 (all other variables remaining constant), the HR profile is only slightly modified and is shifted towards higher values as albedo increases (Fig. 9a). A surface albedo increase means that more radiation is reflected by the surface. The outgoing radiation leaving the surface also interacts with dust layer which increases the overall absorption. This result is in agreement with Heintzenberg et al. (1997), Satheesh et al. (2002) or Raut and Chazette (2008). As a result, an error of $20 \%(0.20 \pm 0.05)$ on the albedo leads to an error of $0.2 \mathrm{Kday}^{-1}$ on the HR in the part of the plume exhibiting the largest AEC (and smaller elsewhere) and an error in the monsoon layer less than about $0.1 \mathrm{Kday}^{-1}$ (Fig. 9e). 
The sensitivity of the heating rate retrievals to the type of surface was also investigated by performing a STREAMER simulation with the surface characterized as vegetation and another with a soil characterized as dry (all other variables being identical). The radiative impact of dust is strongest above vegetated (darker) surfaces (Fig. 9b) consistently with the change in albedo discussed previously. The difference between the surface type leads an error on the order of $0.2 \mathrm{Kday}^{-1}$ on the heating rate profile in the aerosol layer and a slightly smaller error in the monsoon layer (Fig. 9e).

Profiles issued from dropsondes released on 13 June every $2^{\circ}$ along the Niamey-Cotonou transect were used to compute the heating rates at $10^{\circ} \mathrm{N}$ on 14 June. The sensitivity of the heating rate retrievals to the temperature, pressure and water vapor mixing ratio profiles were found to be negligible, except below the dust layer where it is very small between 0 and $0.2 \mathrm{Kday}^{-1}$ (not shown).

Concerning ozone, HR profiles were found not to be sensitive to the total column (not shown). The sensitivity was tested for a value of 280 Dobson.

We also have tested the sensitivity of the HR profiles to the BER value. As stated in Sect. 2.2, a value of $0.02 \mathrm{sr}^{-1}$ was selected for the inversion of the LEANDRE 2 data, while a value of $0.024 \mathrm{sr}^{-1}$ (modulated by a factor accounting for multiple scattering and ranging between 0.95 and 0.65 ) was chosen for the inversion of the CALIOP data (Sect. 2.3.1). Recent studies evidenced that that BER variations associated with dust in this region of the globe are generally less than 20\% (Wandinger et al. (2010), Omar et al. (2009)). Hence, we have analyzed the sensitivity of the LEANDRE 2-derived HR to an error of $\pm 0.004 \mathrm{sr}^{-1}$ on the BER values, i.e. for BER values ranging from 0.016 to $0.024 \mathrm{sr}^{-1}$. An increase of the BER leads to a decrease of HR values throughout the profile (Fig. 7c). The error resulting from uncertainties on the BER can be as high as $1.7 \mathrm{Kday}^{-1}$ in the optically thickest part of the dust plume, in agreement with the results of Berthier et al. (2006). The error in the monsoon layer, i.e. below the dust plumes $\left(\approx 1 \mathrm{Kday}^{-1}\right)$, are found to be larger than those in the upper, optically less thick, part of the plume $\left(\approx 0.6 \mathrm{Kday}^{-1}\right)$.

Finally, the error on the dust HR associated with an uncertainty of $10 \%$ on the aerosol extinction coefficient profile retrieved from lidar measurements was taken into account. Dust HR increases with AEC as shown by Fig. 9d. The maximum error is located in dust layer and is on the order of $0.25 \mathrm{Kday}^{-1}$.

Figure 9e shows the expected uncertainties on the HR profile associated with the error sources identified above. The largest uncertainties (or $\Delta \mathrm{HR}$ ) are related to errors on the BER, all other variables remaining equal. The same uncertainty is found on the HR whether a $+10 \%$ or a $-10 \%$ error is considered for the extinction. The same is true also when one considered an albedo of 0.15 or 0.25 .

The total uncertainty on the HR values, taken as the sum of the quadratic errors related to the type of soil, the albedo, the BER and the extinction, can be written as:

$$
\begin{gathered}
\sigma_{\Delta \mathrm{HR}}=\left[\left(\mathrm{HR}_{\mathrm{alb} 0.15}-\mathrm{HR}_{\mathrm{alb} 0.20}\right)^{2}+\left(\mathrm{HR}_{\mathrm{dry}}-\mathrm{HR}_{\mathrm{vegeted}}\right)^{2}\right. \\
+\left(\mathrm{HR}_{\mathrm{BER}} 0.020 \pm 0.004-\mathrm{HR}_{\mathrm{BER}} 0.020\right)^{2} \\
\left.+\left(\mathrm{HR}_{\mathrm{ext} 10}-\mathrm{HR}_{\mathrm{ext}}\right)^{2}\right]^{1 / 2}
\end{gathered}
$$

In all cases, the total uncertainty is computed with respect to the reference profile. Because the uncertainty is mainly sensitive to the BER value, two profiles are shown in Fig. 9f : a profile corresponding to the minimum total uncertainty and a profile corresponding to the maximum total uncertainty. Figure $9 f$ evidences that the uncertainty in the thickest part of the plume was between 0.6 and $1.3 \mathrm{Kday}^{-1}$, and less than that in the upper part of the plume. These values were also found to be representative of the average total uncertainties computed along the entire F/F20 transect while only considering cloud-free lidar profiles.

\subsubsection{Cloudy conditions}

We have tested the sensitivity of the HR profiles to the BER values, as in the previous section. As observed for the cloudfree profiles, increased BER values lead to decreased heating rate values throughout the profile (Fig. 10a). Resulting uncertainties are comprised between 0.5 and $1.1 \mathrm{Kday}^{-1}$ in the optically thickest part of the dust plume (Fig. 10e). As in cloud-free condition, HR profiles were found not to be sensitive to the total column values prescribed in STEAMER (not shown).

The sensitivity of HR profiles to the cloud radiative, optical and structural properties were then tested for: (i) cloud physical thickness (Fig. 10b), (ii) cloud optical depth (Fig. 10c), and (iii) cloud particle effective radius (Fig. 10d). Heating rates profiles were found to be insensitive to water concentration (not shown). Sensitivity tests were made based on the standard deviation of the MODIS-derived clouds properties.

The influence of the cloud physical thickness on the heating rate profiles is mainly located in the immediate vicinity of the cloud layer (Fig. 10b, e). The maximum of HR in the cloud is found to be stronger for the shallower cloud (i.e. $10 \mathrm{~m}$ ). The maximum is found to be located higher because the reference of physical thickness is at the top of the cloud. The error relative to the reference value $(45 \mathrm{~m})$ is null in most of the aerosol layer (Fig. 10e) and is more important in the lower part of the plume, in the cloud layer. Large uncertainties on the HR are obtained for very shallow clouds $\left(3.6 \mathrm{Kday}^{-1}\right)$.

The sensitivity of the HR profiles to the cloud optical thickness values is analyzed next for extreme values ranging from 1 to 14.95 (Fig. 10c). An increase of the optical thickness leads to an increase of heating rate values throughout the profile. Important errors are also found at the bottom of the dust layer, in the vicinity of the cloud top. They are smaller for optically thicker clouds $\left(0.2 \mathrm{Kday}^{-1}\right.$ for an optical depth of 14.95 versus $2 \mathrm{Kday}^{-1}$ for an optical depth of 

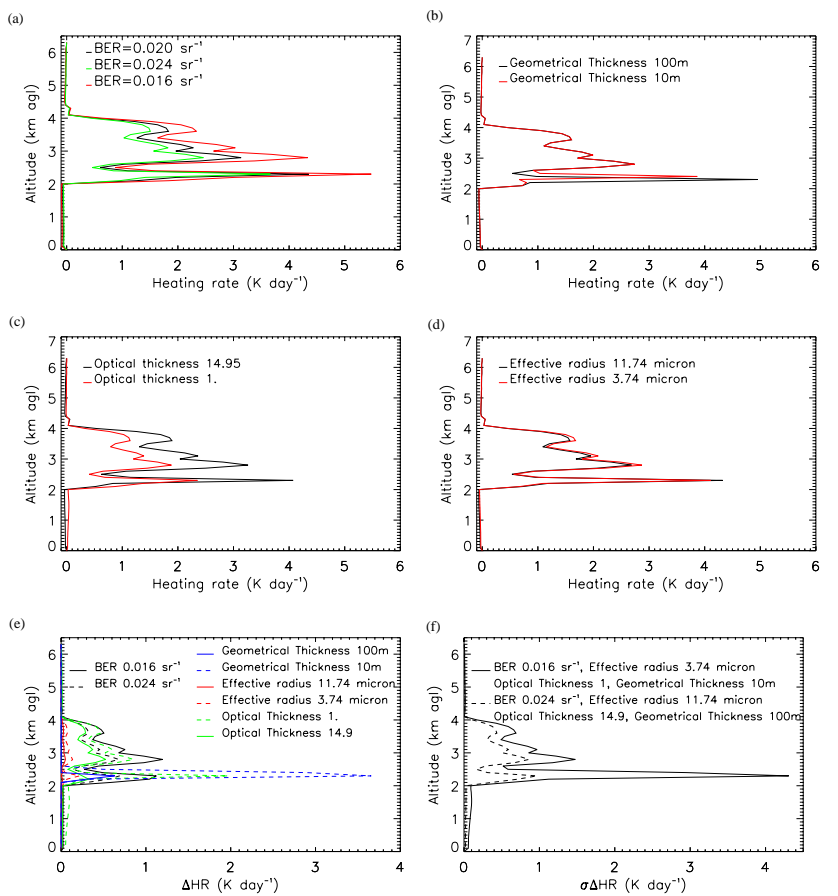

Fig. 10. Sensitivity of the LEANDRE-derived heating rate profile at $5^{\circ} \mathrm{N}$ on 14 June to: (a) dust BER, (b) cloud geometrical depth, (c) cloud optical thickness and (d) effective radius of cloud particles. Uncertainties (in $\mathrm{Kday}^{-1}$ ) for each of the previous variables are shown in (e). Uncertainties are computed with respect to reference profile shown in Fig. 7c and using the $\mathrm{RaCH}$ model. The total uncertainty on the HR, taken as the sum of the quadratic errors of all variable previously shown are shown in (f): the dashed line corresponds to the minimum total uncertainty and the solid line corresponds to the maximum total uncertainty (see text for details).

1). In the core of the dust plume, the maximum uncertainties are on the order of $0.9 \mathrm{Kday}^{-1}$ for optically thick clouds and $0.6 \mathrm{Kday}^{-1}$ for optically thin clouds.

Finally, the sensitivity of the heating rate retrievals to the cloud particle effective radius was found to be quite small (Fig. 10d). The largest uncertainties are found at the bottom of the dust layer, in the vicinity of the cloud top $\left(0.2 \mathrm{Kday}^{-1}\right)$. Uncertainties are smaller for smaller effective radius. In the core of the dust plume, the maximum uncertainties are on the order of $0.1 \mathrm{Kday}^{-1}$.

The total uncertainty on the HR values, taken as the sum of the quadratic errors related the variables described above, was also computed in the case of cloudy profiles (Fig. 10f). The largest total uncertainties in the dust plume are associated with a BER of $0.016 \mathrm{sr}^{-1}$, a cloud particle effective radius of 3.74, a cloud physical thickness of $10 \mathrm{~m}$ and an cloud optical thickness of 1 . The smallest uncertainty is obtained a BER of $0.024 \mathrm{sr}^{-1}$, a cloud particle effective radius of 14.9, a cloud physical thickness of $100 \mathrm{~m}$ and an cloud optical thickness of 14.9. Figure 10f evidences that the uncertainty in the thickest part of the plume was between 0.8 and $1.3 \mathrm{Kday}^{-1}$, and less than that in the upper part of the plume. The largest uncertainties are associated with HR retrievals just above the cloud layer (between 1 and $4.3 \mathrm{Kday}^{-1}$ ). These values were also found to be representative of the average total uncertainties computed along the entire F/F20 transect while only considering cloudy lidar profile.

We have to bear in mind that a cooling effect at the level of the cloud is observed for a reference case, without aerosols. The previous results highlight that a dust aerosol layer overlying a cloud reduces the cloud cooling effect mentioned above. This is due to an attenuation thought the dust layer of the radiative irradiances reaching the cloud. In comparison to the reference case the resulting effect is a local warming of the atmosphere at the cloud location.

\subsection{Daytime observations}

\subsubsection{Radiative impact from LEANDRE 2 data}

Figure 11a and 11b show the heating rates HRs associated with dust on 13 June computed using the $\mathrm{RaCH}$ and CHOM models, respectively, and the AEC shown in Fig. 6b. Figure $11 \mathrm{~d}$ and e represent the HR associated with dust on 14 June 2006 computed using the $\mathrm{RaCH}$ and CHOM models, respectively, and the AEC shown in Fig. 6d.

Maximum values of the heating rates are observed at the location of maximum dust-related AEC. They are mainly due to the shortwave contributions (for more than 60\%). Two regions of particularly high heating rates (in excess of $6 \mathrm{Kday}^{-1}$, reaching $8 \mathrm{Kday}^{-1}$ in some instances, see Fig. 11) are seen between $6^{\circ} \mathrm{N}$ and $10^{\circ} \mathrm{N}$ (above the cumulus clouds over vegetated Benin) and between $12^{\circ}$ and $15^{\circ} \mathrm{N}$ (over the drier Sahel). A weak but non negligible HR (on the order of $1 \mathrm{Kday}^{-1}$ ) is observed in the monsoon layer. HRs in excess of $2 \mathrm{Kday}^{-1}$ (resp. $3 \mathrm{Kday}^{-1}$ ) are generally observed to be associated with the thickest part of the dust plume using the $\mathrm{RaCH}$ (resp. CHOM) model. The difference between the HRs obtained with the CHOM and $\mathrm{RaCH}$ models on 13 June can reach values as large as $3 \mathrm{Kday}^{-1}$ (Fig. 11c). The higher HRs retrieved with the CHOM model likely reflect the fact that the dusts in this model are characterized by lower SSA values in the visible (Fig. 4c, d). On 13 June, the average heating rate difference in the dust layer is about $1 \mathrm{Kday}^{-1}$.

On 14 June, the heating rates derived from the $\mathrm{RaCH}$ model (Fig. 11d) and CHOM model (Fig. 11e) are smaller than on 13 June. Differences in heating rates between the two days are on the order of several $\mathrm{Kday}^{-1}$ and are most significant north of $12^{\circ} \mathrm{N}$ (Fig. 12). On 14 June, the highest heating rates are seen in the form of a thin layer between $7^{\circ}$ and $10^{\circ} \mathrm{N}$, mostly above the cumulus clouds covering southern Benin. On 14 June, the average heating rate difference in the dust layer is about $0.7 \mathrm{Kday}^{-1}$ (Fig. 11f). 
(a)

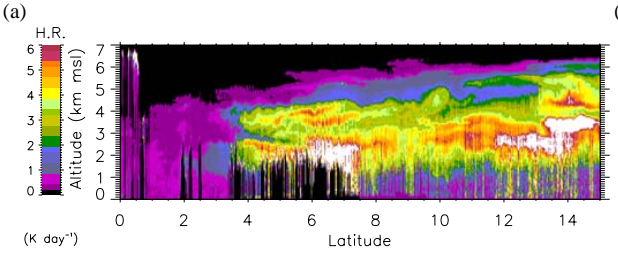

(d)
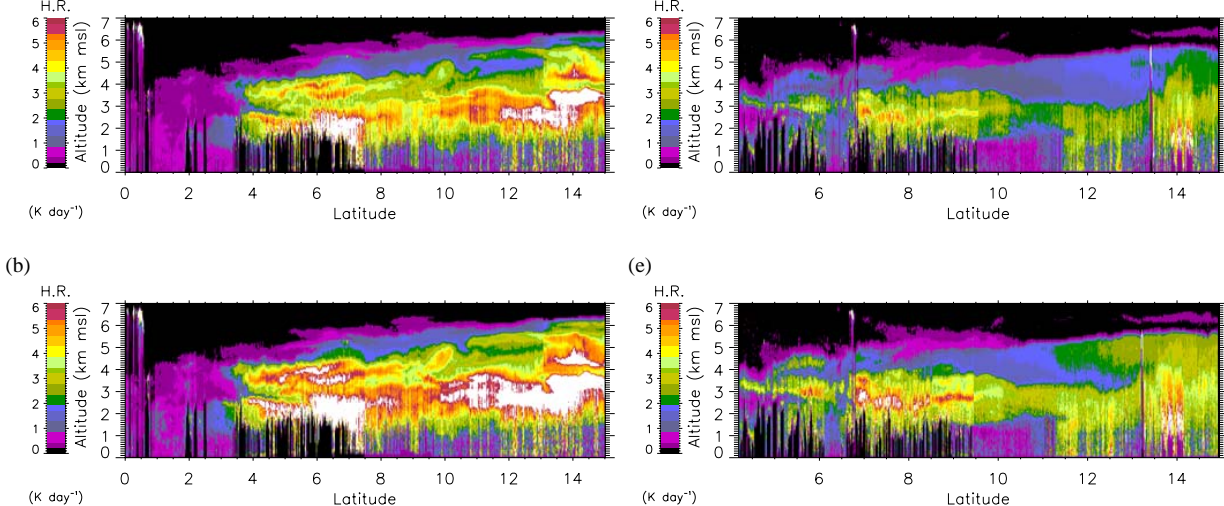

(c)

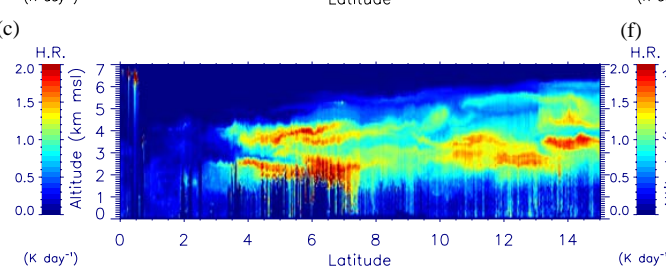

(e)
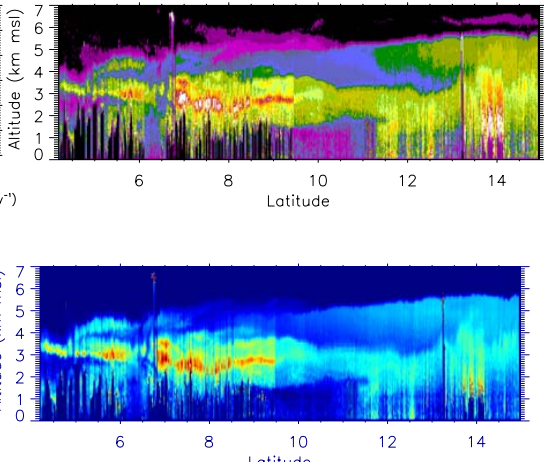

Fig. 11. Heating rate transect derived from LEANDRE 2 aerosol extinction coefficient profiles on 13 June 2006 using the RaCH model (a) and and the CHOM model (b). (c) The difference between the two heating rate fields shown in (a) and (b). (d), (e) and (f) are as in (a), (b) and (c) but on 14 June 2006.
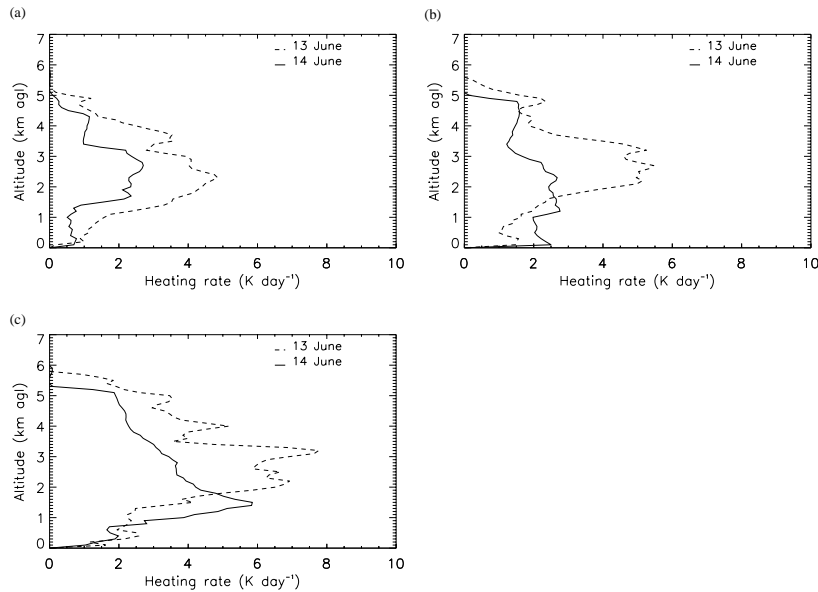

Fig. 12. Heating rate profiles derived from LEANDRE 2 on 13 June (dashed line) and 14 June (solid line) at $10^{\circ} \mathrm{N}(\mathbf{a}), 12^{\circ} \mathrm{N}(\mathbf{b})$ and $14^{\circ} \mathrm{N}$ (c) with the $\mathrm{RaCH}$ model.

\subsubsection{Radiative impact from CALIOP data}

The same procedure is followed to quantify the radiative impact of dust using data gathered by CALIOP. Results are presented in Fig. 13 for the daytime CALIPSO track on 14 June. The HRs corresponding to the CALIOP AEC crosssection is shown for both the RaCH model (Fig. 13b) and the CHOM model (Fig. 13c). Finally, the difference between the HRs retrievals from the two aerosol models is shown in
Fig. 13d. The black areas correspond to regions located below clouds were calculation cannot be done since the reflectivity signal is strongly impacted by clouds or totally attenuated. The radiative forcing in the dust plume is observed to be in excess of about $2 \mathrm{Kday}^{-1}$ in the region located between 3 and $5 \mathrm{kmm}$.s.l. from $6^{\circ}$ to $35^{\circ} \mathrm{N}$ (Fig. 13b, c). The strongest HRs are observed to be on the order of 3 to $4 \mathrm{Kday}^{-1}$, i.e. slightly less than what was observed by LEANDRE 2 for instance in the region between 6 and $15^{\circ} \mathrm{N}$. In particular, CALIOP seems to be missing the thin layer of high HR values observed by LEANDRE 2 around $3 \mathrm{~km} \mathrm{~m}$.s.l. between $6^{\circ}$ and $10^{\circ} \mathrm{N}$ (also see Sect. 5.3.3). The difference between the HRs derived from the two aerosol models is about $0.8 \mathrm{Kday}^{-1}$ on average in the dust layer and can reach $2 \mathrm{Kday}^{-1}$ locally, particularly above the cumulus clouds over southern Benin, as observed with LEANDRE 2. In this case also, the difference in HRs observed with the CHOM model are caused by the more absorbing dust properties of this model with respect to the $\mathrm{RaCH}$ model.

\subsubsection{Comparison of results obtained with LEANDRE 2 and CALIOP}

Vertical cross section of AEC and radiative HRs deduced from LEANDRE 2 and CALIOP AEC profiles show coherent results. In both datasets, the maximum heating rate is located between $6^{\circ} \mathrm{N}$ and $15^{\circ} \mathrm{N}$ as well as between 2 and $5 \mathrm{~km}$ m.s.l., i.e. in the AEJ which was shown by Flamant et al. (2009) to extend from 5 to $14^{\circ} \mathrm{N}$ and between 2 and $5 \mathrm{~km}$ m.s.l. over Benin and southern Niger (Fig. 14). 

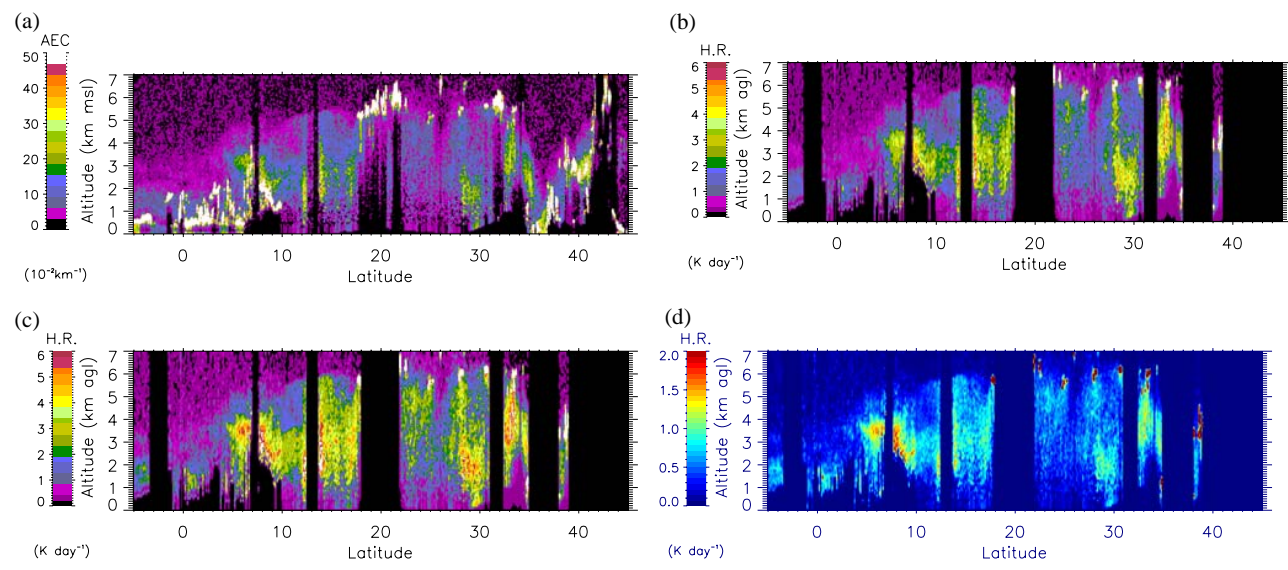

Fig. 13. (a) Aerosol extinction coefficient profiles derived from the CALIOP lidar on 14 June at 13:20 UTC. Heating rate derived using the $\mathrm{RaCH}$ model (b) and the CHOM model (c).(d) The difference between the two heating rate fields shown in (b) and (c).
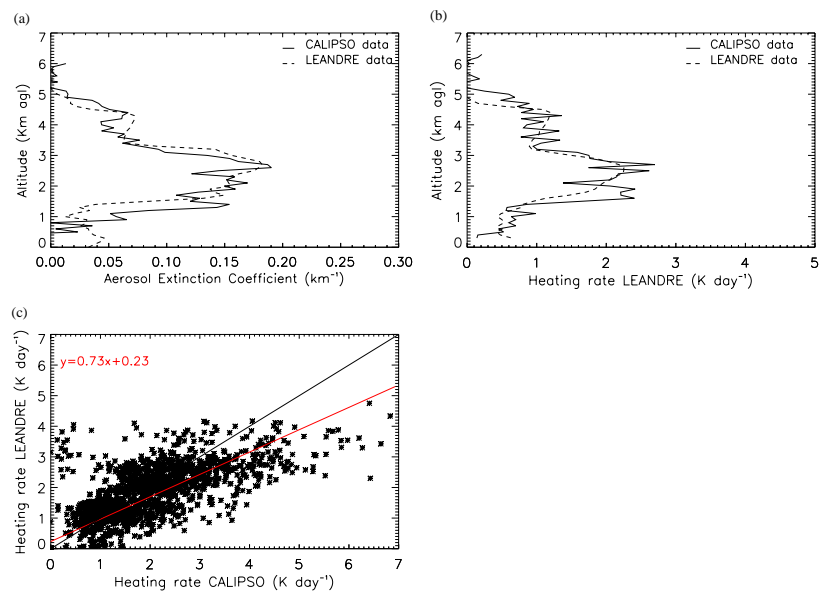

Fig. 14. Comparison of (a) AEC and (b) heating rate profiles with $\mathrm{RaCH}$ model on 14 June at $12^{\circ} \mathrm{N}$ derived from LEANDRE 2 (solid line) and from CALIOP (dash line). (c) Scatter plot of the profileto-profile comparison of heating rates obtained with LEANDRE 2 and CALIOP between $5^{\circ}$ and $15^{\circ} \mathrm{N}$. The linear regression trough the cluster is given by the red solid line.

In spite of good agreement between the LEANDRE 2 and CALIOP heating rate retrievals, the latter were always observed to be greater than the former, except in the monsoon layer. As an example, Fig. 14a shows the vertical profile of the AEC at $12^{\circ} \mathrm{N}$ for the two instruments and the corresponding vertical profile of the HR at the same latitude (Fig. 14b). The AEC profiles are seen to be in good agreement in the upper part of the dust layer (between 2 and $5 \mathrm{~km}$ a.g.l.) and to be somewhat different below $2 \mathrm{~km}$ a.g.l. The difference below $2 \mathrm{~km}$ a.g.l. is related to the correction of the attenuation in the lidar inversion technique discussed in Sect. 2. Given that LEANDRE 2 measurements were acquired from a much lower altitude and just above the dust plume, the signal-to-noise ra- tio (20) is much greater than for CALIOP (1 at $532 \mathrm{~nm}$ and at night, for an horizontal resolution of $1 \mathrm{~km}$ and a vertical resolution of $60 \mathrm{~m}$ ) which enables a better correction of the dust-induced attenuation (assuming an unbiased BER value) and to obtain more realistic backscatter and AEC values in the monsoon layer below the dust layer.

The HR is slightly greater for CALIPSO $\left(+0.2 \mathrm{Kday}^{-1}\right.$ on average for the profile) than for LEANDRE. However, in some instances, the difference between the two profiles can reach $0.5 \mathrm{Kday}^{-1}$ as for example below the dust layer, in the monsoon layer (Fig. 14b).

A profile-to-profile comparison between HRs retrieved with CALIOP and LEANDRE is shown in Fig. 14c. For the comparison, approximately 10 LEANDRE 2 profiles were averaged together to match the spatial resolution of CALIOP. Only HR values in the dust plume (between 2 and $5 \mathrm{~km}$ a.g.1.) and in excess of $0.15 \mathrm{Kday}^{-1}$ are concerned here. Overall, we find a marked tendency for CALIOP-derived HRs to be overestimated with respect to the LEANDREderived heating rates (see regression line in Fig. 14c). Nevertheless, there is a fair agreement between the CALIOPderived and LEANDRE-derived HRs for values comprised between 0.5 and $3 \mathrm{Kday}^{-1}$. The correlation coefficient between the CALIOP- and LEANDRE-derived heating rate is around 0.85 .

\subsubsection{The importance of radiative forcing in the longwave spectral domain during daytime}

In this study, the contribution of the HR in the longwave is accounted for. Generally only HRs in the shortwave part of the spectrum are considered (e.g. Saha et al. (2008), Dubovik et al. (2002), Satheesh et al. (2006)) since the contribution of longwave is supposed to be negligible. Nevertheless, during the SHADE campaign, Highwood et al. (2003) evidenced a warming at the surface (up to $0.5 \mathrm{Kday}^{-1}$ ) and a cooling 

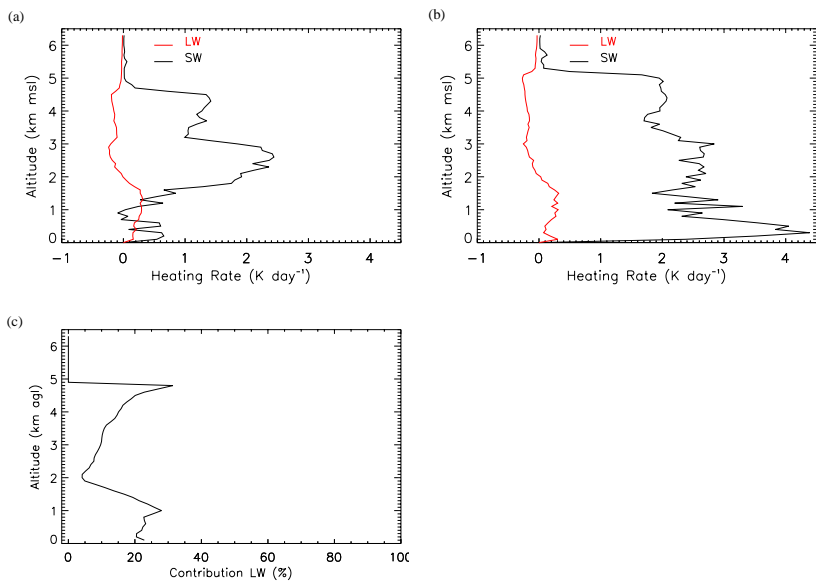

Fig. 15. Heating rate profiles in the longwave domain (red solid line) and in the shortwave domain (black solid line) derived from LEANDRE 2 at $10^{\circ} \mathrm{N}$ (a) and $13^{\circ} \mathrm{N}$ (b) with the RaCH model. (c) Relative contribution of the longwave to the total heating rate averaged along the entire F/F20 transect on 14 June.

within a Saharan dust plume (up to $0.5 \mathrm{Kday}^{-1}$ ) in the longwave, over the Atlantic Ocean.

The contribution of the radiative forcing in the longwave ( 4 to $400 \mu \mathrm{m}$ ) and shortwave $(0.28$ to $4 \mu \mathrm{m}$ ) parts of the spectrum to the total radiative forcing is shown at two locations along the F/F20 transect $\left(10^{\circ} \mathrm{N}\right.$ in Fig. $15 \mathrm{a} ; 13^{\circ} \mathrm{N}$ in Fig. 15b). In the case of the northernmost profile, the contribution of the forcing in the longwave is observed to be small (Fig. 15b) and is less than 10\%. Cooling is observed in the dust plume in both cases, while warming is seen below the dust plume, in the monsoon layer. In the case of the southern profile, the impact in the longwave is on the order of that in the shortwave. This is likely related to the lesser amount for dust present in the monsoon layer at sourthern latitudes.

The mean contribution of the radiative forcing in the longwave was investigated along transect (Fig. 15c). It is on the order of $20 \%$ in the monsoon layer, while only being on the order of $10 \%$ in the dust layer. The maximum contribution of the longwave is observed at the top of the aerosol layer and at the top of the monsoon layer. On average, the contribution of the shortwave is more important in the dust layer than in the monsoon layer (Fig. 15c).

\subsection{Nighttime observations}

Estimating dust related HR during the nighttime is essential to fully understand the radiative impact of the dust transported in the AEJ region across West Africa on the monsoon dynamics. Because such dust transport episodes can last for a few days and nights, and because the radiative impact of the advected dust will be likely be different whether dust interact with longwave and shortwave radiations or just longwave ra- diations, the effect on the atmospheric dynamics is expected to be different.

The radiative impact of the dust plume from Eastern Africa was also investigated using nighttime CALIOP data over Ghana, Bukina-Faso and Niger (Fig. 1a). In the early hours of 13 June, a distinct dust plume was observed between $8^{\circ} \mathrm{N}$ and $15^{\circ} \mathrm{N}$, and between 2 and $4.5 \mathrm{~km}$ m.s.l.(Fig. 16a). A thin layer of aerosol was also observed south of $8^{\circ} \mathrm{N}$ at about $3 \mathrm{~km} \mathrm{~m} . \mathrm{s} .1$. The radiative impact of dust during the night is quite different from that observed during the day, because of the contribution of the longwave only (Fig. 16b, c). In this case, a radiative cooling on the order of 0.2 to $0.8 \mathrm{Kday}^{-1}$ is retrieved in the dust layer, while a warming is seen below the dust layer $\left(0.2\right.$ and $\left.0.6 \mathrm{Kday}^{-1}\right)$. These results are in agreement with the findings of Stone et al. (2007), ? and Highwood et al. (2003). Furthermore, the radiative impact derived from the RaCH model (Fig. 16b) and the CHOM model (Fig. 16c) are identical (not shown), even though the two models exhibit discrepancies in the longwave part of the spectrum in terms of SSA (Fig. 4a), asymmetry factor (Fig. 4c) and AEC (Fig. 4e). This suggests that the heating rate in the longwave is not very sensitive to the aerosol model ( $\mathrm{RaCH}$ or $\mathrm{CHOM})$.

\section{Summary and conclusion}

The present study has evaluated a new approach to quantify the radiative impact of dust from airborne LEANDRE 2 and space-borne CALIOP lidar observations using a two mineral dust models constrained by airborne in situ data and ground-based sun-photometer. Complementary space-borne observations (from MODIS) and in-situ observations such as dropsondes are also used. The sensitivity of the so-derived heating rate is also analyzed for some key variables for which the associated uncertainties are quite large.

We demonstrate the benefit of lidar-derived AEC to determine the HR profiles. This is particularly crucial if one wants to thoroughly understand the radiative forcing feedback on atmospheric boundary-layer dynamics. Furthermore, we have analyzed the contribution of the forcing in the longwave part of the spectrum during the daytime and the nighttime. This is essential if one wants to fully understand the radiative impact of the long-lasting dust episodes transported in the AEJ region across West Africa on the monsoon dynamics.

To the best of the authors, this study is the comprehensive observational study to thoroughly explore at the same time the variability of the HR on the vertical within a dust plume, the contribution of longwave radiation to the HR and radiative forcing of dust during the night. Past studies analyzing dust-related HR retrievals over the African continent have dealt with column integrated HR retrievals. Over the ocean, Highwood et al. (2003) have provided evidence of the importance of the longwave contribution to radiative 
(a)

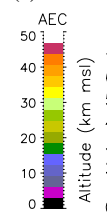

(c)

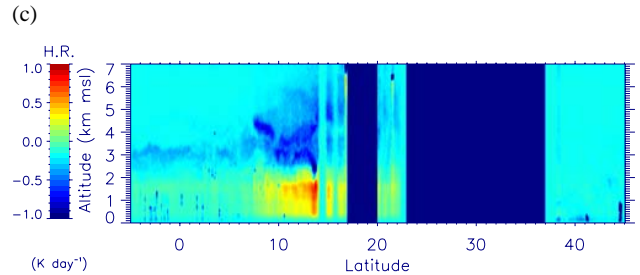

(b)
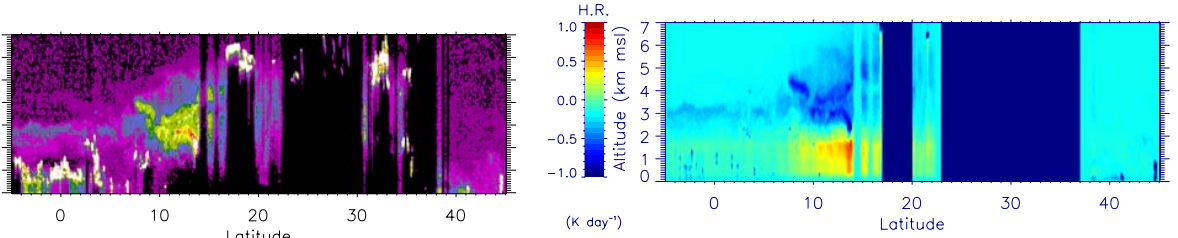

Fig. 16. Aerosol Extinction coefficient profiles derived from the CALIOP lidar on 13 June at 01:39 UTC (a). Heating rate derived using the $\mathrm{RaCH}$ model (b) and the CHOM model (c).

heating/cooling associated with dust plumes advected from the continent.

In this paper, we focus on an intense and long-lasting episode of dust being lifted in remote sources in Chad and Sudan and transported across West Africa in the AEJ region. This episode (9-15 June 2006) was well documented in the framework of the AMMA SOP, particularly on 13 and 14 June, when airborne and space-borne lidar data were acquired over some AMMA ground-based instrumental sites in Benin and Niger.

During the daytime, the warming associated with the presence of dust aerosols was found to be between $1.5 \mathrm{Kday}^{-1}$ and $4 \mathrm{Kday}^{-1}$, on average, depending on altitude and latitude which is in agreement with previous studies. For instance, Dimri and Jain (1999) found maximum heating rates between $2.2 \mathrm{Kday}^{-1}$ in winter and $2.53 \mathrm{Kday}^{-1}$ in summer, for dust transport episodes in the Sahara. Also Saha et al. (2008) found heating rates on the order of $3.47 \mathrm{Kday}^{-1}$ to be associated with dust events occurring over the French Mediterranean coastal zone. In the present case, strong warming (i.e. heating rates as high as $8 \mathrm{Kday}^{-1}$ ) was also observed locally in some limited part of the dust. Large vertical gradients of heating rates are also evidenced between the optically thickest and thinnest parts of the plume (up to $3 \mathrm{Kday}^{-1}$ ). The uncertainty on the heating rate retrievals in the optically thickest part of the dust plume was estimated to be between 0.5 and $1.4 \mathrm{Kday}^{-1}$. Warming was also observed in the monsoon layer, due to the presence of dust in that layer as well. In cloud-free conditions (over northern Benin and Niger), the HR was observed to scale with the lidar-derived AEC. Over cumulus type clouds (present at the top of the monsoon layer over southern Benin and over the Gulf of Guinea), the largest HRs were observed just over the cloud. The largest uncertainties on the HR profiles are related to uncertainties on the BER. We also show that in the dust plume, the longwave contribution to the HR is on the order of $5-15 \%$. Below, in the monsoon layer, this contribution increases to $20 \%$ near the surface.

During the nighttime, much smaller values of heating/cooling are retrieved (less than $\pm 1 \mathrm{Kday}^{-1}$ ). Furthermore, cooling is observed as the result of the longwave forcing in the dust layer, while warming is observed below the dust layer, in the monsoon layer.

The availability of this information over West Africa thanks to the CALIOP platform will allow in the future evaluating the effect of dust event on the monsoon regime. Thus the next step of this work aims at quantifying the effect of dust over the whole West Africa using CALIPSO data producing three-dimensional maps of radiative forcing for the 9-15 June dust episode. The temporal and spatial variability of dust impact will be scrutinized and analyzed in relationship with the monsoon dynamics. Particular attention will be given to the impact of the transported dust on the dynamic of the AEJ and the modification of the development of westerly African waves through alterations of horizontal temperature gradient.

Acknowledgements. Based on a French initiative, AMMA was built by an international scientific group and is currently funded by a large number of agencies, especially from France, UK, US and Africa. It has been the beneficiary of a major financial contribution from the European Communitys Sixth Framework Research Programme. Detailed information on scientific coordination and funding is available on the AMMA International web site http://www.amma-international.org. The authors wish to thank the SAFIRE (Service des Avions Français Instrumentés pour la Recherche en Environnement, www.safire.fr), the Institut Géographique National (IGN, www.ign.fr) and the Division Technique of the Institut National des Sciences de l'Univers (DT/INSU,www.dt.insu.cnrs.fr) for preparing and delivering the research aircraft (Falcon 20/F-GBTM and the ATR42) and the airborne instruments in a timely manner for the AMMA SOP. They also wish to thank the AMMA Operation Center and their partners across West Africa for smoothing out many aspects of the 
airborne operations. The authors are grateful to D. Bruneau and P. Genau (LATMOS), F. Blouzon, A. Abchiche, D. Chaize, and N. Amarouche (DT/INSU) for re-fitting and operating the LEANDRE 2 system in the F/F20. Special thanks to A. Gribkoff, R. Caillou and M. Laurens (SAFIRE) for operating the dropsonde system, and to N. Grand (LISA, previously DT-INSU) for operating the AVIRAD system. The authors thank CNRS-INSU for financial support for this publication. We also wish to thank Bernard Cappelaere for delivering irradiance data on Wankama station.

Edited by: J. Williams

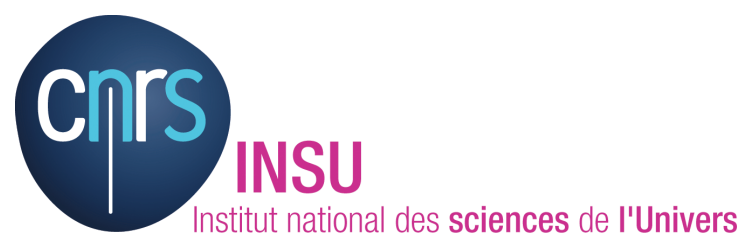

The publication of this article is financed by CNRS-INSU.

\section{References}

Ackermann, J., Völger, P., and Wiegner, M. : Significance of Multiple Scattering from Tropospheric Aerosols for Ground-Based Backscatter Lidar Measurements. Appl. Opt. 38, 24, 5195-5201, doi:10.1364/AO.38.005195, 1999.

Alfaro S., Gaudichet, A., Gomes, L., and Maillé, M.: Mineral aerosol production by wind erosion: aerosol particle sizes and binding energies, Geophys. Res. Lett., 25, 991-994, 1998.

Anderson, T. L. and Ogren, J. A.: Determining Aerosol Radiative Properties using the TSI 3563 Integrating Nephelometer, Aerosol Sci. Technol., 29(1), 57-69, 1998.

Balkanski, Y., Schulz, M., Claquin, T., and Guibert, S.: Reevaluation of Mineral aerosol radiative forcings suggests a better agreement with satellite and AERONET data, Atmos. Chem. Phys., 7, 81-95, doi:10.5194/acp-7-81-2007, 2007.

Berthier, S., Chazette, P., Couvert, P., Pelon, J., Dulac, F., Thieuleux, F., Moulin, C., and Pain, T.: Desert dust aerosol columnar properties over ocean and continental Africa from Lidar in-Space Technology Experiment (LITE) and Meteosat synergy, J. Geophys. Res., 111, D21202, doi:10.1029/2005JD006999, 2006.

Bierwirth, E., Wendisch, M., Ehrlich, A., Heese, B., Tesche, M., Althausen, D., Schladitz, A., Mller, D., Otto, S., Trautmann, T., Dinter, T., von Hoyningen-Huene, W., and Kahn, R. : Spectral surface albedo over Morocco and its impact on radiative forcing of Saharan dust. Tellus, 61B, 252-269, doi:10.1111/j.16000889.2008.00395.x., 2009.

Briegleb, B. P, Minnis, P., Ramanathan, V., and Harrison, E.: Comparison of regional clear-sky albedos inferred from observations and model calculation, J. Climate Appl. Meteor., 25, 214-226, 1986.

Bruneau, D., Quaglia, P., Flamant, C., Meissonnier, M., and Pelon, J.: The airborne lidar LEANDRE II for water-vapor profiling in the troposphere, I. System description, Appl. Opt. 40, 34503475, 2001.
Chomette, O.: Modélisation et analyse meso-échelle du cycle de l'aérosol désertique. Aspects radiatifs et dynamiques. $\mathrm{PhD}$ thesis, Université de Lille, 1999.

Collins, D. R., Johnson, H. H., Seinfeld, J. H., Flagan, R. C., Gasso, S., Hegg, D. A., Schmid, B., Russell, P. B., Livingston, J. M., Ostro E., Noone, K. J., Russell, L. M. and Putaud, J. P.: In situ aerosol size distributions and clear column radiative closure during ACE-2. Tellus 52B, 498-525, 2000.

Cuesta, J., Edouart, D., Mimouni, M., Flamant, P. H., Loth, C., Gibert, F., Marnas, F., Bouklila, A., Kharef, M., Ouchene, B., Kadi, M., and Flamant, C. A.: Multi-platform observations of the seasonal evolution of the Saharan atmospheric boundary layer in Tamanrasset, Algeria, in the framework of the African Monsoon Multidisciplinary Analysis field campaign conducted in 2006, J.Geophys. Res., 113, D00C07, doi:10.1029/2007JD009417, 2008.

Cuesta, J., Marsham, J. H., Parker, D. J., and Flamant, C.: Dynamical mechanisms controlling the vertical redistribution of dust and the thermodynamic structure of the West Saharan Atmospheric Boundary Layer during Summer, Atmos. Sci. Lett., 10, 1, 34 42, 2009.

Dimri, A. P. and Jain, V. K.: Radiative effect of desert aerosols, Current Science, 77(1), 163-166, 1999.

Dubovik, O., Smirnov, A., Holben, B. N., King, M. D., Kaufman, Y. J., Eck, T. F., and Slutsker, I.: Accuracy assessments of aerosol optical properties retrieved from AERONET sun and sky-radiance measurements, J. Geophys. Res., 105, 9791-9806, 2000.

Dubovik, O., Holben, B., Exk, T., Smirnov, A., Kaufman, Y., King, M., Tanré, D., Slutsker, I.: Variability of Absorption and Optical Properties of Key Aerosol Types Observed in Worldwide Locations, J. Atmos. Sci., 59, 590-608, 2002.

Dunion, J. P. and Velden, C. S.: The impact of the Saharan air layer on Atlantic tropical cyclone activity, BAMS, 353-365, doi:10.117/BAMS-85-3-353, 2004.

Evan, A. T., Dunion, J., Foley, J. A., Heidinger, A. K., Velden, C. S.: New evidence for a relationship between Atlantic tropical cyclone activity and African dust outbreaks, Geoph. Res. Lett., 33, L19813, doi:10.1029/2006GL026408, , 2006.

Fernald, F. G., Herman, B. M., and Reagan, J. A.: Determination of aerosol height distributions by lidar, J. Atmos. Meteor., 11, 482-489, 1972.

Fernald, F. G.: Analysis of atmospheric lidar observations: some comments, Appl. Opt., 23, 652-653, 1984.

Flamant, C., Chaboureau, J.-P., Parker, D. P., Taylor, C. M., Cammas, J. P., Bock, O., Timouk, F., and Pelon, J.: Airborne observations of the impact of a convective system on the planetary boundary-layer thermodynamics and aerosol distribution in the intertropical discontinuity region of the West African Monsoon, Q. J. Roy. Meteorol. Soc., 133, 1175-1189, 2007.

Flamant, C., Lavaysse, C., Todd, M., Chaboureau, J. P., and Pelon, J.: Multi-platform observations of a representative springtime case of Bodele and Sudan dust emission, transport and scavenging over West Africa, Q. J. Roy. Meteorol. Soc., 135, 413-430, 2009.

Formenti P., Grand, N., Chevaillier, S., Schmechtig, C., and Desboeufs, K.: Airborne observations of aerosol particles over western Africa in the summer monsoon season: Spatial and vertical variability of physico-chemical and optical properties, Atmos. 
Chem. Phys., to be submitted, 2010.

Grams, G., Blifford Jr., I. H., Gillette, D. A., and Russell, P. B.: Complex index of refraction of airbone soil particles, J. Appl. Meteorol., 13, 459-471, 1974.

Heinold, B., Tegen, I., Schepanski, K., and Hellmuth, O.: Dust radiative feedback on Saharan boundary layer dynamics and dust mobilization, Geophys. Res. Lett., 35, L20817, doi:10.1029/2008GL035319, 2008.

Heintzenberg, J., Charlson, R. J., Clarke, A. D., et al.: Measurements and modeling of aerosol single-scattering albedo: progress, problems and prospects, Beitr. Phys. Atmosph., 5(70), 249-263, 1997.

Heintzenberg, J.: The SAMUM-1 experiment over Southern Morocco: overview and introduction, Tellus, 61B, 2-11, 2009.

Highwood, J. E, Haywood, J. M. Silverstone, M. D., Newman, S. M., and Taylor, J. P.: Radiative properties and direct effect of Saharan dust measured by the C-130 aircraft during Saharan Dust Experiment (SHADE): 2. Terrestrial spectrum, J. Geophys. Res., 108(D18), 8578, doi:10.1029/2002JD002552, 2003.

Intergovernmental Panel on Climate Change (IPCC), Climate Change 2007: The Scientific Basis. Contribution of Working Group I to the Third Assessment Report of the Intergovernmental Panel on Climate Change, edited by: Solomon, S., Qin, D., Manning, M., Chen, Z., Marquis, M., Averyt, K. B., Tignor, M., and Miller, H. L., Cambridge Univ. Press, New York, USA, 881 pp. 2007.

Johnson, B. T.: The semi direct aerosol effect, Phd thesis, University of Reading, UK, 2003.

Johnson, B. T., Shine, K. P., and Forster, P. M.: The semi-direct aerosol effect: Impact of absorbing aerosols on marine stratocumulus, Q. J. Roy. Meteorol. Soc., 130, 1407-1422, 2004.

Key, J. and Scheiger, A. J.: Tools for atmospheric radiative transfer: Streamer and FluxNet, Comp. Geosci., 24(5), 443-451, 1998.

Key, J.: Streamer User's Guide. Cooperative Institute for Meteorological Satellite Studies, University of Wisconsin, USA, 96 pp., 2001.

Kim, S.-W., Chazette, P., Dulac1, F., Sanak, J., Johnson, B., and Yoon, S.-C.: Transport and vertical structure of aerosols and water vapor over West Africa during the African monsoon dry season, Atmos. Chem. Phys., 9, 8017-8038, doi:10.5194/acp-98017-2009, 2009.

Lebel, T., Parker, D. J., Flamant, C., Bourles, B. , Marticorena, M., Mougin, E., Peugeot, C., Diedhiou, A., Haywood, J. M., Ngamini, J. B., Polcher, J., Redelsperger, J.-L., and Thorncroft, C. D.: The AMMA field campaigns: Multiscale and multidisciplinary observations in the West African region, Q. J. Roy. Meteorol. Soc., 136, S1, 8-33, 2010.

Liu, Z., Omar, A., Vaughan, M., Hair, J., Kittaka, C., Hu, Y., Powell, K., Trepte, C., Winker, D., Hostetler, C., Ferrare, R., and Pierce, R.: CALIPSO lidar observations of the optical properties of Saharan dust: A case study of long-range transport, J. Geophys. Res., 113, D07207, doi:10.1029/2007JD008878., 2008.

Messager, C., Parker, D. J., Reitebuch, O., Agusti-Panareda, A., Taylore, C. M., and Cuesta, J.: Structure and dynamics of the Saharan atmospheric boundary layer during the West African monsoon onset: Observations and analyses from the research flights of 14 and 17 July 2006, Q. J. Roy. Meteorol. Soc., 136(S1), 107124, doi:10.1002/gj.469, 2010.

Mishchenko, M. I., Travis, L. D., and Macke, A.: Scattering of light by polydisperse, randomly oriented, finite circular cylinders, Appl. Opt., 35, 4927-4940, 1996.

Mohalfi, S., Bedi, H. S, Krishnamurti, T. N., and Cocke, S. D.: Impact of shortwave radiative effects of dust aerosols on the summer season Heat Low over Saudi Arabia, Amer. Meteorol. Soc., 126, 3153-3167, 1998.

Nicolas, F., Bissonnette, L. R., and Flamant, P. H.: Lidar effective multiple-scattering coefficients in cirrus clouds. Appl. Opt. 36, 3458-3468, 1997.

Ogawa, K. and Schmugge, T.: Mapping Surface Broadband Emissivity of the Sahara Desert using ASTER and MODIS data, Amer. Meteorol. Soc., 8(7), 1-14, 2004.

Omar, A. H., Winker, D., Kittaka, C., Vaughan, M. A., Liu, Z., Hu, Y., Trpte, C. R., Rogers, R. R, Ferrare, R. A., Lee, K.P., Kuehn, R. E., and Hostetler, A.: The CALIPSO Automated Aerosol Classification and Lidar Ratio Selection Algorithm, J. Atmos. Ocean. Technol., 26, 1994-2014, 2009.

Prospero, J. M., Ginoux, P., Torres, O., and Nicholson, S. E.: Environmental characterization of global sources of atmospheric soil dust derived from the NIMBUS7 TOMS absorbing aerosol product, Rev. Geophys., 40(1), 1002, doi:10.1029/2000RG000095, 2002.

Raut, J.-C. and Chazette, P.: Radiative budget in the presence of multi-layered aerosol structures in the frame of AMMA SOP0, Atmos. Chem. Phys., 8, 6839-6864, doi:10.5194/acp-8-68392008, 2008.

Redelsperger, J. L., Thorncroft, C., Diedhiou, A., Lebel, T., Parker, D. J., and Polcher, J., et al.: African Monsoon Multidisciplinary Analysis: An International Research Project and Field, BAMS, (December 2006), 87(12), 1739-1746. 2006.

Roman, M., Schaaf, C. B., Lewis, P., Gao, F., Anderson, G. P., Privette, J. L., Strahler, A. H., Woodcock, C. E., and Barnsley, M.: Assessing the coupling between surface albedo derived from MODIS and the fraction of diffuse skylight over spatiallycharacterized landscapes, Remote Sens. Environ., 114, 738-760, 2010.

Saha, A., Mallet, M., Roger, J. C, Dubuisson, P., Piazzola, J., and Despiau, S.: One year measurements of aerosol optical properties over an urban coastal site: Effect on local direct radiative forcing, Atmos. Res., 90, 195-202, 2008.

Satheesh, S. K. V. Ramanathan, V., Holben, B. N., Moorthy, K. K., Loeb, N. G., Maring, H., Prospero, J. M., and Savoie, D.: Chemical, microphysical and Radiative Properties of Indian Ocean Aerosols, J. Geophys. Res., 107(D23), 4725, doi:10.1029/2002JD002463, 2002.

Satheesh, S. K., Deepshikha, S., and Srinivasan, J.: Impact of dust aerosols on Earth-atmosphere clear-sky albedo and its short wave radiative forcing over African and Arabian regions, Int. J. Remote Sens., 27(8), 1691-1706, 2006.

Sokolik, I. N. and Toon, O. B.: Incorporation of mineralogical composition into models of the radiative properties of mineral aerosol from UV to IR wavelengths, J. Geophys. Res., 104(D8), 94239444, 1999.

Solmon, F., Mallet, M., Elguindi, N., Giorgi, F., Zakey, A., and Konaré, A.: Dust aerosol impact on regional precipitation over western Africa, mechanism and sensitivity to absorption properties, Geophys. Res. Lett., 35, L24705, doi:10.1029/2008GL035900, 2008.

Stephens, G. L., Vane, D. G., Boain, R. J., Mace, G. G., Sassen, 
K., Wang, Z., Illingworth, A. J., O'Connor, E. J., Rossow, W. B., Durden, S. L., Miller, S. D., Austin, R. T., Benedetti, A., Mitrescu, C., and CloudSat Science Team: The CloudSat mission and the A-train: A new dimension of space-based observations of clouds and precipitation, Bull. Amer. Meteorol. Soc., 83, 17711790, doi:10.1175/BAMS-83-12-1771, 2002.

Stone, R. S., Anderson, G. P., Andrews, E. , Dutton, E. G., Shettle, E. P., and Berk, A.: Incursions and radiative impact of Asian dust in northern Alaska, Geophys. Res. Lett., 34, L14815, doi:10.1029/2007GL029878, 2007.

Tanre, D., Deroo, C., Duhaut, P., Herman, M., Morcrette, J. J., Perbos, J., and Deschamps, P. Y.: Simulation of the satellite signal in the solar spectrum (5S), Lab. Opt. Atmos., 262 pp., 1986.

Tegen, I., Heinold, B., Todd, M., Helmert, J., Washington, R., and Dubovik, O.: Modelling soil dust aerosol in the Bodélé depression during the BoDEx compaign, Atmos. Chem. Phys., 6, 43454359, doi:10.5194/acp-6-4345-2006, 2006.

Tesche, M., Ansmann, A., Müller, D., Althausen, D., Mattis, I.n Heese, B., Freudenthaler, V., Wiegner, M., Esselborn, M., Pisani, G., and Knippertz, P.: Vertical profiling of Saharan dust with Raman lidars and airborne HSRL in southern Morocco during SAMUM, Tellus, Ser. B, 61, 144-164, doi:10.1111/j.16000889.2008.00390.x., 2009.

Todd, M. C., Washington, R., Raghavan, S., Lizcano, G., and Knippertz, P.: Regional model simulations of the Bodele low-level jet of northern Chad during the Bodélé Dust Experiment (BoDEx 2005), J. Climate, 21, 995-1012, 2008.

Tsay, S.-C., Stamnes, K., and Jayaweera, K.: Radiative energy budget in the cloudy and hazy Arctic, J. Atmos. Sci., 46, 1002-1018, 1989.

Voltz, F. E.: Infrared optical constants of ammonium sulfate, Sahara dust, volcanic pumice and flyash, Appl. Opt., 12, 564-568, 1973.

Wandinger, U., Tesche, M., Seifert, P., and Ansmann, A.: Size matters: Influence of multiple scattering on CALIPSO lightextinction profiling in desert dust, Geophys. Res. Lett., 37, L10801, doi:10.1029/2010GL042815, 2010.
Washington, R., Todd, M. C., Engelstaedter, S., Mbainayel, S., and Mitchell, F.: Dust and the low-level circulation over the Bodele Depression, Chad: Observations from BoDEx 2005, J. Geophys. Res., 111, D03201, doi:10.1029/2005JD006502, 2006.

Weingartner, E., Saatho, H., Schnaiter, M., Streit, N., Bitnar, B., and Baltensperger, U.: Absorption of light by soot particles: determination of the absorption coefficient by means of aethalometers, Aerosol Sci., 34, 1445-1463, 2003.

Weinzierl, B., Petzold, A., Esselborn, M., Minikin, A. Fix, A., Wirth, M., and Fiebig, M.: The Airborne Aerosol Measurements During SAMUM-1 and SAMUM-2: What Have we Learned About Dust?, AGU Fall Meeting 2008, San Francisco, CA, USA, 15-19 December 2008, A41K-08, 2008.

Welton, E. J., Voss, K. J., Gordon, H. R., Maring, H. , Smirnov, A., Holben, B., Schmid, B., Livingston, J. M., Russell, P. B., Durkee, P. A., Formenti, P., and Andreae, M. O.: Groundbased lidar measurements of aerosols during ACE-2: Instrument description, results, and comparisons with other groundbased and airborne measurements, Tellus Ser. B, 52, 636-651, 2000.

Winker, D., Hunt, W., and McGill, M.: Initial performance assessment of CALIOP, Geophys. Res. Lett., 34, L19803, doi:10.1029/2007GL030135, 2007.

Winker, D. M., Vaughan, M. A, Omar, A., Hu, Y., Powell, K. A., Liu, Z., Hunt, H. W., and Young, S. A. : Overview of the CALIPSO mission and CALIOP data processing algorithms, J. Atmos. Ocean. Technol., 26, 2310-2323, 2009

Young, S., Winker, D., Vaughan, M., Hu, Y., and Kuehn, R.: Extinction Retrieval Algorithms, CALIOP Algorithm Theoretical Basis Document PC-SCI-202 Part 4, available online at: http://www-calipso.larc.nasa.gov/resources/project_ documentation.php, 2008. 